\title{
Geographical isolation, habitat shifts and hybridisation in the diversification of the Macaronesian endemic genus Argyranthemum (Asteraceae)
}

Oliver W. White ${ }^{1,2,3}$, J. Alfredo Reyes-Betancort ${ }^{4}$, Mark A. Chapman ${ }^{2}$ and Mark A. Carine ${ }^{1}$

${ }^{1}$ Algae, Fungi and Plants Division, Department of Life Sciences, The Natural History Museum, Cromwell Road, London, SW7 5BD, United Kingdom

${ }^{2}$ Biological Sciences, University of Southampton, Southampton, SO17 1BJ, United Kingdom.

${ }^{3}$ Royal Botanic Gardens, Kew, Richmond, Surrey TW9 3AE.

${ }^{4}$ Jardín de Aclimatación de La Oratava (Instituto Canario de Investigaciones Agrarias - ICIA), C/

Retama 2, 38400 Puerto de la Cruz, Tenerife, Spain

ORCID iDs

Oliver White 0000-0001-6444-0310

Mark A. Chapman 0000-0002-7151-723X

Social media (Twitter)

Olive W.White @Ollie_W_White

J. Alfredo Reyes-Betancort @AlfredoJAOICIA

Mark A.Chapman @CUCsoton

Mark A. Carine@mark_carine

Corresponding author: Mark A. Carine (m.carine@nhm.ac.uk, 02079425541)

$\begin{array}{ll}\text { Summary } & 200 \\ \text { Introduction } & 1,112 \\ \text { Material and Methods } & 2,373 \\ \text { Results } & 1,481 \\ \text { Discussion } & 1,523 \\ \text { Main body } & 6,489 \\ & \\ \text { Number of Figures } & 5 \\ \text { Number of Tables } & 4\end{array}$

Supporting Information Supporting-Information-Table-S8

Supporting-Information-Table-S9

Supporting-Information-Methods-S2 


\section{Summary}

- Inferring the processes responsible for the rich endemic diversity of oceanic island floras is important for our understanding of plant evolution and setting practical conservation priorities. This requires an accurate knowledge of phylogenetic relationships, which have often been difficult to resolve due to a lack of genetic variation.

- We employed genotyping-by-sequencing (GBS) to investigate how geographical isolation, habitat shifts, and hybridisation have contributed to the evolution of diversity observed in Argyranthemum Webb (Asteraceae), the largest genus of flowering plants endemic to the Macaronesian archipelagos.

- $\quad$ Species relationships were resolved, and biogeographical stochastic mapping identified intra-island speciation as the most frequent biogeographic process underlying diversification, contrary to prevailing view in Argyranthemum and the Canary Islands. D-statistics revealed significant evidence of hybridisation between lineages co-occurring on the same island, however there was little support for the hypothesis that hybridisation may be responsible for the occurrence of non-monophyletic multi-island endemic (MIE) species.

- Geographic isolation, habitat shifts, and hybridisation have all contributed to the diversification of Argyranthemum, with intra-island speciation found to be more frequent than previously thought. Morphological convergence is also proposed to explain the occurrence of non-monophyletic MIE species. This study reveals greater complexity in the evolutionary processes generating Macaronesian endemic diversity.

Keywords

Argyranthemum, genotyping-by-sequencing, biogeography, biogeographic stochastic mapping, hybridisation, Macaronesia, morphological convergence, speciation 
 Introduction}

Investigations of the processes responsible for the unique assemblage of flowering plants on oceanic archipelagos are informative for our understanding of plant evolution and may also inform practical conservation policies (Caujapé-Castells et al., 2010; Bramwell, 2011). The Macaronesian archipelagos of the Azores, Madeira, Selvagens, the Canary Islands and the Cape Verdes in the North Atlantic Ocean have been considered a region ideally suited to investigations of the processes responsible for flowering plant evolution (Kim et al., 2008). Macaronesia is home to approximately 30 endemic genera and 900 endemic species of flowering plants (Caujapé-Castells et al., 2010) and diversification of lineages within the region has played a prominent role in generating the striking levels of endemic diversity.

Hypotheses to explain diversification of plant lineages within Macaronesia and other such archipelagos have largely focussed on geographical isolation (i.e. speciation through isolation following inter-island dispersal between similar ecological niches) and habitat shifts (i.e. speciation associated with the shifts of a lineage to different ecological niches; Francisco-Ortega et al., 2002; Lee et al., 2005; Goodson et al., 2006). Hybridisation has also been recognised as an important process for diversification in oceanic archipelagos, although much less is known about its frequency and evolutionary significance (Jones et al., 2014; Curto et al., 2017). Instances of hybridisation have been inferred from incongruence between chloroplast (cp) and nuclear DNA datasets (Mort et al., 2002; Barber et al., 2007; Jones et al., 2014) or quantified through the use of D-statistics (ABBABABA tests) that can discern between incomplete lineage sorting and hybridisation (Eaton \& Ree, 2013; Curto et al., 2017).

A significant impediment to our understanding of the relative contribution of these processes in generating the observed diversity on oceanic islands has been the lack of phylogenetic resolution in studies based typically on sequencing the nuclear internal transcribed spacer region (ITS) or analysing one or a few cp loci (Francisco-Ortega et al., 1997b; Mort et al., 2002; Allan et al., 2004; Trusty et al., 2005; Goodson et al., 2006; Barber et al., 2007). To overcome this, recent studies have employed high-throughput sequencing (HTS) approaches, particularly reduced representation style data such as restriction site associated markers (RAD-seq) and genotyping-by-sequencing (GBS; Baird et al., 2008; Elshire et al., 2011). These methods are advantageous as they identify thousands of polymorphic markers across multiple samples in non-model species without the need for a reference 
genome. A caveat of these methods is that RAD-seq or GBS loci are typically too short and lack sufficient variation to be analysed individually. However, the loci generated by these methods may be concatenated to create a supermatrix containing thousands of polymorphic sites and have been employed successfully in the resolution of phylogenetic relationships between closely related taxa in Macaronesia, notably Tolpis Adans. (Asteraceae; Mort et al., 2015) and Micromeria Benth. (Lamiaceae; Puppo et al., 2015), as well as taxa in other island systems including Dyospiros (Ebenaceae; Paun et al., 2016). In each of these examples, the reduced representation datasets considerably improved the resolution of species relationships and allowed greater inference of the processes responsible for diversification.

Argyranthemum Webb (Asteraceae) is the largest endemic genus of flowering plants found in the Macaronesian archipelagos, with a total of 24 species and 39 terminal taxa (i.e. species and subspecies;

Fig. 1). Three species are endemic to Madeira, one to Selvagem Pequena and twenty to the Canary Islands. Twenty-one species are single island endemics (SIEs) and three are multiple island endemics (MIEs; A. frutescens, A. broussonetii and A. adauctum). Each MIE is comprised of SIE subspecies. Argyranthemum is present in all the major habitat zones in Macaronesia, ranging from coastal to subalpine habitats.

Previous phylogenetic analyses using small numbers of molecular markers have found that Argyranthemum is monophyletic and closely related to the continental genera Glebionis Cass., Heteranthemis Schott and Ismelia Cass. that are distributed in the Mediterranean, Southern Iberia and Morocco, respectively (Francisco-Ortega et al., 1995a,b; Oberprieler et al., 2007). However, attempts to resolve species relationships within Argyranthemum have been hampered by a lack of genetic variation (Francisco-Ortega et al., 1997a). A cp restriction site analysis identified two main clades, one restricted to Madeira and the Selvagens and one comprising taxa from the Canary Islands (Francisco-Ortega et al., 1996b). Within the Canary Islands clade, two major groups were resolved, one largely corresponding to taxa occupying habitats under the influence of the Northern trade winds and the other not, suggesting that inter-island colonisation between similar habitats was the prominent driver of diversification in the Canary Islands (Francisco-Ortega et al., 1996b). In contrast, habitat shifts were more frequent on Madeira where there was a single colonisation event followed by divergence into different habitat types. 
Hybridisation is also likely to have played a significant role in the diversification of Argyranthemum. Intrinsic reproductive barriers between taxa are weak, with reproductive isolation largely due to geographical and ecological differentiation (Francisco-Ortega et al., 1997a). Artificial hybrids can be created with ease in cultivation (Humphries, 1973) and hybrid swarms have been documented between $A$. broussonetii and $A$. frutescens (Tenerife; Brochmann, 1987), A. coronopifolium and $A$. frutescens (Tenerife; Brochmann, 1984), A. adauctum and A. filifolium (Gran Canaria; Borgen, 1976) and $A$. tenerifae and $A$. adauctum (Tenerife; White, pers. obs.). Hybridisation has also been inferred from the presence of polyphyletic taxa in previous phylogenetic analyses, notably $A$. adauctum (Francisco-Ortega et al., 1996b). It has also been hypothesised that $A$. escarrei is of hybrid origin based on morphological similarity to individuals collected from hybrid swarms between $A$. adauctum subsp. canariense and A. filifolium (Borgen, 1976), although this is not supported by preliminary data (O. White, M.A. Chapman and M.A. Carine, unpublished data). To date, the most robust support for the role of hybridisation in the diversification of Argyranthemum relates to A. sundingii and A. lemsii, for which molecular data clearly support independent homoploid hybrid origins from crosses between A. broussonetii and A. frutescens (Brochmann et al., 2000; Fjellheim et al., 2009; White et al., 2018).

The aim of this study was to investigate the role of geographical isolation, habitat shifts and hybridisation in the evolution of Argyranthemum. To this end, we present a phylogenetic analysis of Argyranthemum using GBS and sampling across the entire genus. Ancestral ranges for geography and habitats are inferred and biogeographic stochastic mapping is performed to estimate the frequency of biogeographic events. To detect evidence of hybridisation we employed D-statistics (Eaton \& Ree, 2013). We specifically tested two hypotheses to assess the role of hybridisation in the diversification of Canary Island lineages: first, that hybridisation between species on the same island has been frequent, as proposed for Micromeria (Curto et al., 2017), and second, that hybridisation explains the non-monophyly of multi-island endemic (MIE) species as proposed for Pericallis (Jones et al., 2014).

\section{Materials and Methods}

\section{Sampling}

Field collections of Argyranthemum were made in the Canary Islands and Madeira from July to August 2015 and March 2016 respectively. Outgroup samples of Glebionis were collected in 
Andalucía, Spain during April 2015. Leaf material was dried and preserved using silica gel for molecular work. Herbarium vouchers were also prepared and deposited at the Natural History Museum, London (BM). Material from the Selvagens was sampled from the University of Madeira Herbarium.

Samples of all Argyranthemum taxa recognised by Humphries (1976) and Francisco-Ortega et al. (1996b) were included in our study (Table 1 ) with the exception of $A$. sundingii and $A$. lemsii which are of hybrid origin (Brochmann et al., 2000; Fjellheim et al., 2009; White et al., 2018) and likely to confound phylogenetic analyses (Gruenstaeudl et al., 2017; McVay et al., 2017). "Argyranthemum vincentii" has been identified in previous studies as an endemic to Tenerife and restricted to pine forest habitats (Francisco-Ortega et al., 1996c, 2000) and can be distinguished from closely-related taxa by filiform leaf lobes and green (not glaucous) leaves (pers. com., A. Santos-Guerra). This taxon has yet to be formally described but was nevertheless included Where possible we included two samples for each terminal taxon, ideally from different populations. However, only one sample could be included for $A$. haematomma, $A$. thalassophilum and for each subspecies of $A$. pinnatifidum. Additionally, for each of the following taxa, two individuals from the same population were sampled: A. adauctum subsp. dugourii, subsp. erythrocarpon, subsp. palmensis, A. frutescens subsp. canariae, A. lidii, A. sventenii, "A. vincentii" and A. winteri. The outgroup taxa, Glebionis segetum and $G$. coronaria from the Mediterranean region, were selected on the basis of earlier phylogenetic analyses (Francisco-Ortega et al., 1995b,a; Oberprieler et al., 2007).

\section{DNA isolation and GBS}

DNA was extracted from silica-dried leaf material using a modified CTAB method (Doyle \& Doyle 1987) identical to the method used by White et al. $(2016,2018)$. DNA samples were sent to the Genomic Diversity Facility at Cornell University for GBS where samples were digested using EcoT22I and single-end $100 \mathrm{bp}$ reads were generated using an Illumina Hiseq. Raw sequence data for $A$. broussonetii subsp. broussonetii, $A$. frutescens subsp. frutescens and subsp. succulentum used by White et al. (2018) were reanalysed in the present study.

\section{Processing of GBS data} 2013) employing the same assembly method as White et al. (2018). Briefly, the sequence quality of 
filtered reads were also removed. Reads were clustered at three different similarity thresholds $(80 \%$, 85\% and 90\%) and reads that mapped to the chloroplast genomes of Arabidopsis thaliana (L.) Heynh. (Genbank accession number: NC_000932.1), Helianthus annuus L. (NC_007977.1) or Chrysanthemum indicum L. (NC_020320.1) and the mitochondrial genomes of $A$. thaliana (NC_001282) or H. annuus (KF815390.1) were removed. Assembled loci were filtered such that a locus must include 30 or 38 samples, equivalent to $60 \%$ and $50 \%$ missing data respectively after the removal of low-quality samples (see Results). Additionally, loci with shared heterozygous sites across more than $20 \%$ of the samples were removed as likely paralogous loci. Therefore, a total of six assemblies were produced (Supporting Information Table S 1), which were compared by genetic clustering as detailed in the Supporting Information (Methods S 1, Fig. S 1; Fig. S 2; Table S 2).

\section{Phylogenetic reconstruction}

Loci were concatenated and missing data were added as Ns to create a supermatrix. The optimal model of sequence evolution was identified using ModelTest-NG v.0.1.3 (https://github.com/ddarriba/modeltest). Maximum likelihood (ML) and Bayesian Inference (BI) trees were generated for each dataset using RAxML Next Generation v.0.5.1 (RAxML-NG; Kozlov et al., 2019) and MrBayes v.3.2.6 (Ronquist et al., 2012), respectively. The ML analyses were performed using the transversion model (TVM) with proportion of invariable sites (I) and a gamma distribution (G) for all six datasets (Supporting Information Table S 3). The best ML tree was selected after 1,000 independent searches and bootstrap values were calculated from 1,000 replicates. The TVM $+1+G$ model was not available in MrBayes so we used the second best supported model which was the general time reversible model (GTR) $+1+G$ (Supporting Information Table S 3) for the Bayesian analyses. The $\mathrm{BI}$ analysis had two runs with four chains, $2 \times 10^{6}$ generations and a sampling frequency of 5,000 before computing a 50\% majority rule consensus tree. Each run in the MrBayes analyses was found to converge with average standard deviation of split frequencies $<0.01$ after $2 \times 10^{6}$ generations and effective sample sizes (ESS) ranging from 483 to 635 as reported in Tracer v.1.7.1 (Supporting Information Fig. S 3; Table S 4; Rambaut et al., 2018). For all analyses trees were visualised using ggtree in R (Yu et al., 2017; R Core team, 2020).

\section{Time calibrated species tree estimation}

172 For optimal ancestral range estimation, a time calibrated tree with a single representative per taxon

173 is required, therefore the final step of the ipyrad pipeline was repeated with one representative of 
each taxon (excluding outgroup taxa), selected as the one with the least missing data, using a clustering threshold of $90 \%$ and a minimum sample number of 16 (equivalent to $60 \%$ missing data; see Results). Where taxa were identified as non-monophyletic all samples were included, except for A. frutescens subsp. gracilescens 179 which appeared to be influenced by hybridisation (see Results). Phylogenetic analysis using RAxML-NG was repeated as above.

Using the fixed topology species tree, taxon divergence times were estimated using MCMCTree in PAML (Yang, 2007) , to provide an ultrametric tree for optimal ancestral range estimation. This method has been shown to be an effective means of estimating divergence times using genomic sequence alignments (dos Reis et al., 2016; Thode et al., 2019). Two calibration points were used. Firstly, the root age of Argyranthemum was previously estimated to be ca. 1.5-3.0 MYA (FranciscoOrtega et al., 1997a). Secondly, the age of El Hierro (0.8 MYA) was used as the maximum age for clades endemic to this island (Francisco-Ortega et al., 1997a). Calibration of divergence times for island lineages is challenging and the use of such recent calibration points will result in recent divergence times but the aim, as noted above, is simply to generate an ultrametric tree and not to estimate divergence times or infer evolutionary rates.

The optimal model of sequence evolution identified by ModelTest-NG was the TVM $+1+G$ model. This was not available in MCMCTree so we used the second best supported model which was GTR $+1+G$. used. Two independent runs in MCMCTree were performed to check for convergence using independent rates model with a log-normal distribution, sampling frequency of 100 for 200,000 samples after a burn-in of 20,000 .

\section{Ancestral area and habitat estimation}

The distributions of taxa and the habitats they occupy were determined using 960 occurrence records from fieldwork collections (622 records) and high precision data downloaded from online databases (338 records; https://www.biodiversidadcanarias.es/ accessed June 2019). For each taxon, distribution was scored as the island occupied and 'habitat' as vegetation type. A recent vegetation classification was used to assign taxa to potential vegetation types of taxa in the Canary Islands (del Arco Aguilar \& Rodríguez-Delgado, 2018). Shape files for the vegetation of the Canary Islands were kindly provided by Marcelino del Arco Aguilar (pers. comm., June 2019). Vegetation types recognised by del Arco Aguilar \& Rodríguez-Delgado (2018) were grouped into: (E) Euphorbia scrubland, (T) thermo-sclerophyllous woodland, (L) laurel forest, $(\mathrm{P})$ pine forest and $(\mathrm{S})$ subalpine zone (Supporting Information Table S 5) and occurrence records were scored for these zones using ArcGIS (ESRI, 2019). 
Some occurrence records occurred in vegetation classes such as rocky habitats or canary palm groves that span several of the zones defined here. In these instances, the zone in which those habitats occurred was identified and scored to minimise the number of associated parameters. To minimise the impact of erroneous occurrence data, a taxon was only scored for a habitat zone if a certain proportion of occurrences for the taxon were present. To ensure our analyses were not sensitive to this threshold, we varied the threshold used to filter erroneous data from $0 \%$ to $20 \%$ in steps of $5 \%$. We selected a threshold of $10 \%$ because this identified a best supported model which was largely consistent with the other thresholds tested (Supporting Information Table S 6). In addition, there was no obvious threshold at which the number states per taxon plateaued (Supporting Information Fig. S 4-Fig. S 5).

The classification by del Arco Aguilar \& Rodríguez-Delgado (2018) does not include Madeira or Selvagem Pequena and the six taxa from these islands were scored using the same categories based on current taxonomic knowledge (Supporting Information Table S 7).

To investigate the biogeographic history of Argyranthemum, we estimated ancestral ranges for islands and habitats using the R package BioGeoBEARS (Matzke, 2014). This package allows the comparison of three widely used biogeographic models, namely DEC (dispersal-extinctioncladogenesis; Ree \& Smith, 2008), DIVA (dispersal-vicariance analysis; Ronquist, 1997) and BayArea (Bayesian Inference of Historical Biogeography for Discrete Areas; Landis et al., 2013). These models were originally developed in different frameworks: likelihood for DEC, parsimony for DIVA, and Bayesian for BayAREA. However, BioGeoBEARS implements each in a likelihood framework allowing direct comparison and model selection (Dupin et al., 2017). All models in BioGeoBEARS can also be implemented with an additional parameter $(\mathrm{J})$ which accounts for founder event speciation, where jump dispersal events result in new genetically isolated lineages. However, the DEC+J model has been shown to be inappropriate for founder event speciation or for statistical comparison (Ree \& Sanmartín, 2018), hence we refrained from using it. The model with the best fit was selected based on log-likelihood values and the corrected Akaike Information Criterion model weights (Matzke, 2014). Using the models with the strongest support for geographical and habitat data, we also performed biogeographical stochastic mapping (BSM) in BioGeoBEARS to investigate the number and type of biogeographical events taking place in the evolution of Argyranthemum. A total of 50 biogeographic maps were used. The method identifies anagenetic dispersal events (range contraction or expansion) and cladogenetic events including intra-range speciation (narrow or subset) and vicariance (Fig. 2a; Dupin et al., 2017; Pérez-Escobar et al., 2017). In the context of the 
237

238

239

240

241

242

243

244

245

246

247

248

249

250

251

252

253

254

255

256

257

258

259

260

261

262

263

264

265

oceanic island setting investigated here, we interpret vicariance as inter-island allopatric speciation for geography and as habitat shifts for habitat data. For ancestral range estimation in BioGeoBEARS, the maximum range sizes for geographic and habitat distributions were three (out of nine) and five (out of five) respectively.

\section{D-statistics}

We employed D-statistics as outlined by Eaton and Ree (2013) to test for evidence of hybridisation. Each test takes a four taxon pectinate tree denoted by $(((\mathrm{P} 1, \mathrm{P} 2), \mathrm{P} 3), \mathrm{O})$ and identifies incongruent ancestral (A) and derived (B) alleles denoted as ABBA or BABA (Fig. 2b,c). If ILS is responsible for the incongruence, the proportion of $\mathrm{ABBA}$ and $\mathrm{BABA}$ alleles will be equal; however, if $\mathrm{P} 3$ has hybridised with either $\mathrm{P} 2$ or $\mathrm{P} 1$, we would expect an asymmetry in the number of ABBA or BABA alleles (Fig. $2 b, c)$. The $D$ statistic quantifies the asymmetry of $A B B A$ and $B A B A$ allele frequencies. Following Eaton and Ree (2013), we performed 1,000 bootstrap iterations to measure the standard deviation of the D-statistic, in which loci were re-sampled with replacement to the same number as in the original dataset. The results are reported as $Z$ scores, where $Z$ is the number of standard deviations from 0 (the expected value) for D. Significance is assessed by converting the Z-score into a two-tailed pvalue and using 0.01 as a conservative cut-off after correcting for multiple comparisons using HolmBonferroni correction.

We first used D-statistics to test for evidence of hybridisation between clades found on the same island (Fig. 2d). Seventeen clades were identified as co-occurring on one of the Canary Islands, with two clades on El Hierro, three on La Palma, two on La Gomera, seven on Tenerife and three on Gran Canaria (Supporting Information Fig. S 6). A total of 29 tests were implemented (Table 4): one on EI Hierro (test 1), three on La Palma (tests 2-4), one on La Gomera (test 5), 21 on Tenerife (tests 6-26) and three on Gran Canaria (tests 27-29).

Second, we used D-statistics to test the hypothesis that hybridisation explains the polyphyly of the multi-island endemic species $A$. adauctum and A. broussonetii (See Results; Fig. 2e). Four tests were implemented (Table 4): one for A. broussonetii that was resolved in two distinct clades (test 30) and three for A. adauctum that was resolved in three distinct clades (tests 31-33). We did not test for hybridisation in $A$. frutescens as this was resolved as paraphyletic rather than polyphyletic, with other taxa nested within this species (see Results). 
If hybridisation occurred between close relatives not included in the test, it is possible for D-statistics to produce type 1 errors (Eaton \& Ree, 2013). Therefore, for any D-statistic which gave a significant result, we additionally performed a five-taxon partitioned D-statistic, to identify more precisely which of the P3 taxa contributed to hybridisation. The partitioned D-statistic is an extension of the D-statistic, where the taxa at the $\mathrm{P} 3$ position are separated into $\mathrm{P} 3_{1}$ and $P 3_{2}$ giving the overall tree topology of $\left(\left((\mathrm{P} 1, \mathrm{P} 2),\left(\mathrm{P3}_{1}, \mathrm{P}_{2}\right)\right), \mathrm{O}\right)$. Similar to the four taxon D-statistic, the asymmetry in allele patterns is measured, with the exception that the test identifies whether the derived allele is present in $\mathrm{P}_{1}$ and not $\mathrm{P}_{2}$, present in $\mathrm{P} 3_{2}$ and not $\mathrm{P} 3_{1}$ or present in both. These allele patterns correspond to three D-statistics for each scenario: $D_{1}, D_{2}$ and $D_{12}$ respectively (Eaton \& Ree, 2013). For D-statistics which had a significant result, partitioned D-statistics were implemented by separating the individuals at P3 into all pairwise combinations. For the nineteen D-statistics that were significant (see Results), 183 partitioned D-statistics were performed (Supporting Information Table S 8). Significance is assessed using the same method as above.

For all tests we used outgroup $(0)$ accessions from the Madeira and Selvagem Pequena clade which were resolved as sister to the Canary Islands clade (see Results). We used the dataset based on clustering threshold of $90 \%$ and a minimum sample number of 30 (see justification in Results; Phylogenetic reconstruction). The methodology for running D-statistics in ipyrad can be found in a Jupyter notebook (https://jupyter.org/) within Supporting Information Methods S 2.

\section{Results}

\section{Processing of GBS data}

286 Approximately $219 \mathrm{M}$ raw reads were generated using GBS with an average of $2.65 \mathrm{M}$ per sample

287 (range $0.02-9.27 \mathrm{M}$ ). Filtering of low-quality reads removed $5.71-11.25 \%$ of the total reads per sample resulting in an average of $2.45 \mathrm{M}$ reads retained across all samples (0.02-8.44 $\mathrm{M})$. Seven samples with less than $0.5 \mathrm{M}$ reads were removed (Table 1; Supporting Information Fig. S 7), leaving a total of 76 samples. An average of 2237 (0.08\%) reads per sample mapped to either the mitochondrial or chloroplast reference genomes and were excluded (Supporting Information Table S 9).

Increasing the similarity threshold for de novo clustering resulted in a higher number of clusters and consensus sequences. The average number of clusters per individual were $23,745,26,497$ and 32,946 for thresholds of $80 \%, 85 \%$ and $90 \%$ respectively (Supporting Information Table S 9). The 
equivalent numbers for the average number of consensus sequences were $20,583,23,706$ and 30,865 respectively (Supporting Information Table S 9). Increasing the minimum number of samples required to include a locus from 30 (60\% missing data) to 38 (50\% missing data) reduced the average number of loci across samples included in the assembly by 32.0-34.2\% (Supporting Information Table S9).

\section{Phylogenetic reconstruction}

Seven main clades were consistently recovered across all datasets in both $\mathrm{ML}$ and $\mathrm{BI}$ analyses with very high or maximal ML bootstrap (BS) and Bayesian posterior probability (PP) (ML: Supporting Information Fig. S 8-Fig. S 13 and BI: Fig. S 14-Fig. S 19). Clade A contains all taxa from Madeira and Selvagem Pequena. Clade B comprises accessions of the Tenerife endemic A. broussonetii subsp. broussonetii. Clade $\mathrm{C}$ includes the multi-island endemic $A$. frutescens which is resolved as paraphyletic with respect to $A$. gracile and "A. vincentii" from Tenerife. Clade D includes $A$. tenerifae, A. adauctum subsp. adauctum and subsp. dugourii from Tenerife. Clade E comprises all accessions from Gran Canaria, excluding A. frutescens subsp. canariae. The Tenerife endemics $A$. coronopifolium and $A$. foeniculaceum are grouped together in clade F. Finally, clade $G$ is composed of taxa endemic to the Eastern and Western Canary Islands.

Whilst clades A-G were consistently recovered in all analyses, the relationships between those clades differed in some analyses. For example, clades $B$ and $C$ formed a sister relationship in one $\mathrm{ML}$ analysis (Supporting Information Fig. S 12), however, clade B was sister to all other clades for the remaining $M L$ datasets. Similarly, a sister group relationship was recovered between clades $D$ and clade $\mathrm{E}$ in ML analyses of three datasets (Supporting Information Fig. S 8, Fig. S 10, Fig. S 12), but not for the remaining three $M L$ datasets where clade $D$ was resolved as sister to clades $F$ and $G$. In addition, for the ML analyses based on an $80 \%$ clustering threshold, one outgroup (G. coronaria 797 ) was resolved as sister to the Madeiran clade (Supporting Information Fig. Fig. S 8, Fig. S 9), although these relationships were poorly supported (BS $<70$ ). We carried out all further analyses on the dataset based on a clustering threshold of $90 \%$ and minimum sample number of 30 (Fig. 3) because it had the highest number of SNPs and the modal number of PCA and STRUCTURE clusters (Supporting Information Table S 10; Methods S 1).

Our analysis revealed three non-monophyletic species (Fig. 3). Firstly, accessions of $A$. broussonetii were resolved as polyphyletic, with subsp. broussonetii from Tenerife resolved as sister to clade $C$ containing the multiple island endemic $A$. frutescens, and subsp. gomerensis from La Gomera sister 
to A. callichrysum, also endemic to La Gomera (Fig. 3). Secondly, accessions of A. adauctum were polyphyletic and were resolved in three clades (Fig. 3). The first included A. adauctum subsp. adauctum and subsp. dugourii, resolved in a Tenerife clade (clade D) with $A$. tenerifae. The second was composed of $A$. adauctum subsp. jacobaeifolium, subsp. canariense and subsp. gracile which was resolved in the Gran Canarian clade (clade E). The third clade included A. adauctum subsp. erythrocarpon and subsp. palmensis from El Hierro and La Palma respectively. This was resolved in the Eastern-Western island clade G. Finally, and as noted above, samples of $A$. frutescens were identified as paraphyletic, with $A$. gracile and "A. vincentii" nested within the A. frutescens clade (clade C). In addition, within A. frutescens, subsp. gracilescens was resolved as polyphyletic, with one of the two samples (177) sister to the La Gomera endemics A. frutescens subsp. parviflorum and subsp. foeniculaceum, and the other (179) nested within subsp. frutescens (Fig. 3).

\section{Time calibrated species tree estimation}

After selecting a single representative sample per taxon (except for those identified as being nonmonophyletic or, in the case of $A$. frutescens subsp. gracilescens 179 potentially influenced by hybridisation for which both samples were retained; see above), a total of 40 samples remained (Supporting information Table S 11). This resulted in a dataset with 7,424 loci and 7,277 SNPs, and phylogenetic analysis using RAxML-NG identified identical taxon relationships as the full dataset (Fig. 3; Supporting information Fig. S 20). Independent runs of MCMCTree found similar node dates suggesting good convergence (Supporting information Fig. S 21). Crown group ages for the main clades identified in Argyranthemum were as follows; A=1.72 MYA (highest probability density [HPD]: 1.20-2.22), C=1.75 MYA (HPD: 1.24-2.22), D=1.69 MYA (HPD: 1.19-2.14); E=1.67 MYA (HPD: 1.19-2.1); $\mathrm{F}=1.59$ MYA (HPD: 1.09-2.07) and G=1.84 MYA (HPD: 1.34-2.29).

\section{Ancestral area and habitat estimation}

Model comparisons in BiogeoBEARS identified the best supported model for geographic distribution

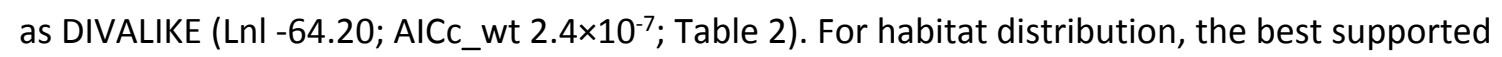
model was BAYAREALIKE ( $\mathrm{Lnl}-112.10$; AICc_wt 0.76; Table 2), and this was robust to varying the threshold for filtering erroneous data (Supporting Information Table S 6). These models were used for all subsequent analyses (Fig. 4; Supporting Information Fig. S 22).

The most likely ancestral area for Clade A was Madeira (Fig. 4) and an inter-island allopatric speciation event was inferred for the Selvagem Pequena endemic $A$. thalassophylum. Clades B, C, D 
and $\mathrm{F}$ originated on Tenerife and within clade $\mathrm{C}$ there were inter-island allopatric events to Gran Canaria and La Gomera. Inter-island allopatry between Tenerife and Gran Canaria was inferred for clade E (Fig. 4). The ancestral area inferred for clade G is La Palma (Fig. 4) and several inter-island allopatry events within this clade are inferred; El Hierro was colonised twice independently and there was a single colonisation of La Gomera and the Eastern islands (Lanzarote and Fuerteventura). The diversification of clades A-G are predominately associated with habitat range contraction, becoming increasing specialised toward the tips of the tree (Fig. 4).

Based on the biogeographic stochastic mapping analyses of geography, intra-island speciation (narrow; 56.62\%) was the most frequent, with inter-island allopatry (vicariance; $22.87 \%$ ) and range expansion (20.51\%) less frequent (Table 3). Note that DIVALIKE models, the most strongly supported model for geography, do not include estimates of intra-range (subset) speciation (Matzke, 2020). For habitats, range contraction (55.99\%) was the most frequent event, followed by intra-habitat (narrow; $36.70 \%$ ) and range contraction (7.30\%; Table 3). For BAYAREALIKE models, the most strongly supported for habitats, it is not possible to infer estimates of intra-range (subset) speciation and vicariance.

In terms of dispersal between islands, Tenerife and La Palma act as the main sources with $39.76 \%$ and $23.66 \%$ of all dispersals occurring from these island respectively (Fig. 5a). There are also some notable differences in directionality. For example, Tenerife never acts as a sink (Fig. 5a) and Gran Canaria is solely a sink (Fig. 5a). For dispersal between habitats, Euphorbia scrub is the greatest source of dispersal events (30.15\%) and the subalpine zone is the habitat most frequently identified as a sink (42.01\%; Fig. $5 b)$.

\section{D-statistics}

Nineteen of the 29 D-statistics (ca. 65\%) between lineages found on the same island provided evidence of hybridisation (Table 4). Of these, 14 were also significant using the partitioned D-statistic. On El Hierro, there was support for hybridisation between the $A$. sventenii-A. hierrense clade and $A$. adauctum subsp. erythrocarpon (test 1; Table 4), which was confirmed by a significant result using partitioned D-statistics. For La Palma, there were significant D-statistics supporting hybridisation between: A. adauctum subsp. palmensis and $A$. webbii (test 3 ) and $A$. haouarytheum and $A$. webbii (test 4). However, only the former was significant when tested with the partitioned D-statistic. Of the 21 D-statistics performed between clades on Tenerife (tests 6-26), 13 provided significant support for hybridisation and all clades examined were admixed with at least two others. Of these, 
11 were also significant using the partitioned D-statistic. On Gran Canaria, there was significant evidence of hybridisation between all three clades based on D-statistics (tests 27-29), but only one of these tests was also significant with partitioned D-statistics.

Between non-monophyletic lineages of MIE species, only one of the four D-statistics performed provided support for evidence of hybridisation, between $A$. adauctum on Tenerife and Gran Canaria (test 31). This test was also significant for the partitioned D-statistic.

\section{Discussion}

Previous phylogenetic analyses of Argyranthemum based on a few molecular markers suggested that diversification was largely explained by geographical isolation by means of inter-island dispersal between similar habitats (Francisco-Ortega et al., 1996b). Several taxa in Argyranthemum were also resolved as non-monophyletic, including the multi-island endemics (MIEs) A. broussonetii, $A$. adauctum and $A$. frutescens (Francisco-Ortega et al., 1996a,b). However, phylogenetic inferences in these analyses were limited by a lack of genetic variation and consequentially poor resolution.

In keeping with the analysis of Francisco-Ortega et al. (1996b), two major clades corresponding to taxa from (1) Madeira and the Selvagens and (2) the Canary Islands were recovered in the present study. However, the two Canary Island subclades previously identified, and predominately restricted to arid and humid habitats respectively, were not recovered. Rather, the ML analysis resolved two clades composed of (1) A. broussonetii subsp. broussonetii and the multi island endemic $A$. frutescens, and (2) all reaming taxa from the Canary Islands (Fig. 3).

The ancestral area for the most recent common ancestor of Argyranthemum was inconclusive, resolved as either Tenerife and Madeira, and the basal split separates a Canary Island clade from that of Madeira and the Selvagem Pequena. Our results suggest that the Selvagem Pequena was most likely colonised from Madeira. Within the Canary Islands, Tenerife acted as the centre of diversity; a pattern suggested for other Canary island radiations such as Lotus (Allan et al., 2004), Cheirolophus (Vitales et al., 2014) and Descurainia (Goodson et al., 2006). Our biogeographic stochastic mapping analyses identifies Tenerife as the main source of dispersal events (39.76\%; Fig. 5), with La Palma also a common source (23.66\%; Fig. 5). The colonisation of the Eastern islands of Lanzarote and Fuerteventura from the Western island of El Hierro revealed by our results is counterintuitive, but was also recovered by Francisco-Ortega et al. (1996b). As an alternative to long distance dispersal, Francisco-Ortega et al. (1996b) hypothesised that this lineage may have followed 
a stepping stone colonisation pattern from West to East, with the lineages on the central islands since becoming extinct. As far as we are aware, there are no other Canary Island endemic lineages showing this West to East relationship. However, there are comparable examples of floristic links between the Western and Eastern islands of the Azorean archipelago (e.g. Schaefer et al., 2011).

Intra-island speciation was found to be most frequent in our biogeographic analysis of geography, accounting for $56.62 \%$ of all events (Table 3). For habitats, biogeographic events were predominantly associated with range contraction (55.99\%) and intra-habitat speciation (narrow) is also common (36.70\%). The pattern of basal nodes having widespread habitat ranges and becoming increasingly specialised (Fig. 4) was a pattern consistently associated with the BAYAREALIKE model for our analysis. BAYAREALIKE models are typically favoured where there are shared widespread ranges in sister species (for example see Litsios et al., 2014). It should be noted, however, that habitat shifts cannot be inferred with BAYAREALIKE models since they do not estimate vicariance.

Taken together, intra-island speciation was found to be predominant in our analysis of geography, contrary to the view that speciation in Canary Island groups is largely driven by inter-island dispersal (Francisco-Ortega et al., 1997a; Baldwin et al., 1999). Within islands, our results do not suggest that habitat shifts are responsible for speciation as suggested for some Macaronesian groups (Barber et al., 2007; Gruenstaeudl et al., 2013). Instead, our habitat analysis suggests that the ancestors of Argyranthemum were potentially widespread generalists that have become increasingly specialised over time.

The topographic complexity of the islands is likely to be an important factor in explaining the prevalence of intra-island speciation processes revealed by our analysis. Such complex landscapes could promote the isolation of lineages at a fine geographic scale leading to narrow endemism. However, we propose that hybridisation could also be an important factor in explaining these patterns. D-statistics (ABBA-BABA tests) suggest that hybridisation between lineages co-occurring on the same islands has been common. D-statistics supported hybridisation in $52 \%(13 / 21)$ of tests performed on Tenerife, two of three tests on La Palma, the single test on El Hierro and all three tests on Gran Canaria. Using partitioned D-statistics which are less susceptible to false positives, hybridisation was supported in in 52\% (11/21) of tests performed on Tenerife, one of three tests on La Palma, the single test on El Hierro (1/1) and one of three tests in Gran Canaria. Taken together with evidence that hybridisation has generated two species by homoploid hybrid speciation (Brochmann et al., 2000; Fjellheim et al., 2009; White et al., 2018), it is clear that hybridisation has 
played a significant role in the evolutionary history and diversification of Argyranthemum, a pattern consistent with the findings in Micromeria (Curto et al., 2017).

A recent review highlighted the role of hybridisation in generating new genetic combinations by reassembly of old variation, thereby facilitating rapid speciation and adaptive radiations (Marques et al., 2019). This "combinatorial view" of speciation has been associated with several adaptive radiations including Darwin's finches (Lamichhaney et al., 2016, 2017; Han et al., 2017), Lake Victoria Cichlids (Meier et al., 2017) and the Hawaiian silversword alliance (Baldwin \& Sanderson, 1998; Barrier et al., 1999). The results presented here suggest that combinatorial processes may also be significant in the diversification of Macaronesian lineages.

Our phylogenetic analysis confirmed that all three MIE species, A. broussonetii, A. adauctum and $A$. frutescens, are non-monophyletic (Fig. 3). Although these findings are in agreement with the analysis of Francisco-Ortega et al. (1996a,b), our analysis provided greater resolution of species and subspecies relationships. Argyranthemum frutescens was resolved as paraphyletic with A. gracile and "A. vincentii" nested within (Fig. 3; clade C). Indeed, based on our phylogenetic analysis, a reconsideration of current taxonomic circumscriptions in the $A$. frutescens clade would be appropriate.

Argyranthemum broussonetii is resolved as polyphyletic with subsp. broussonetii on Tenerife sister to the multi-island endemic $A$. frutescens, whereas subsp. gomerensis on La Gomera is distantly related and is sister to A. callichrysum, also from La Gomera. Based on D-statistics, there was no evidence of hybridisation between $A$. broussonetii subsp. broussonetii and subsp. gomerensis or $A$. callichrysum (Table 4; test 30).

Argyranthemum adauctum was also polyphyletic with three independent clades that corresponded to (1) Gran Canaria (subsp. gracile, canariense and jacobaeifolium), (2) Tenerife (subsp. adauctum and dugourii) and (3) La Palma and El Hierro (subsp. palmensis and erythrocarpon, respectively). Of the three D-statistics performed between clades of $A$. adauctum, only one supported hybridisation (between clades of $A$. adauctum on Tenerife and Gran Canaria; Table 4, test 31).

Curto et al. (2017) was able to infer evidence of hybridisation between lineages of Micromeria distributed across different islands using D-statistics, suggesting that inter-island hybridisation might be a significant process in the diversification of Macaronesian lineages, and Jones et al. (2014) proposed that hybridisation may explains the polyphyly of MIEs in Pericallis. In Argyranthemum, this was only supported in one of the four D-statistics implemented and in the absence of evidence for 
hybridisation in the other MIE tests performed, morphological convergence of distinct evolutionary lineages may better explain the patterns observed.

In the case of $A$. broussonetii, the two subspecies are similar in leaf characteristics, but subsp. gomerensis shows greater affinity to $A$. callichrysum in capitula width and cypselae (dry single seeded fruits) traits (Supporting Information Fig. S 23; White et al., submitted). This suggests that the two have converged on similar leaf traits, potentially in response to the similar habitats in which they occur.

The morphological characters that differentiate the three lineages of $A$. adauctum from other taxa (Humphries, 1976) appear to be more consistent, including hispid or tomentose indumentum, sessile leaves with primary lobes or teeth at the leaf base and wingless and fused ray cypselae (pers. obs.). Although the morphological convergence of $A$. adauctum is less easily explained than in $A$. broussonetii, it remains the most parsimonious explanation for the relationships observed.

Humphries (1976; page 162) noted the potential for convergent evolution in Argyranthemum given the "limited repertoire of leaf shape in the genus". In addition, Lee et al. (2005) proposed convergent evolution as a potential explanation for the non-monophyletic relationships of the genus Taeckholmia in the Sonchus alliance (Asteraceae: Sonchinae), although they were unable to rule out hybridisation as an alternative explanation. Convergent morphological evolution in response to similar habitats on islands has also been reported in Nesotes beetles in the Canary Islands (Rees et al., 2001) and Anolis Lizards of the Greater Antilles (Losos et al., 1998). Nevertheless, convergent morphological evolution has received much less attention in the diversification of flowering plants across Macaronesia compared with geographic isolation, habitat shifts and hybridisation.

\section{Conclusions}

The use of GBS has significantly improved the resolution of phylogenetic relationships in Argyranthemum and revealed greater complexity in the processes responsible for its diversification with geographical isolation, habitat shifts, hybridisation and convergent morphological evolution all inferred. High throughput sequencing (HTS) is increasingly employed for investigations of oceanic island endemic lineages (Mort et al., 2015; Paun et al., 2016; Curto et al., 2017) and further studies of Macaronesian lineages using HTS are likely to provide the power to discern the complexity of the processes acting to generate flowering plant diversity in the region. 
509

510

511

512

513

514

515

516

517

518

519

520

521

522

523

524

525

526

527

528

529

530

531

532

533

534

535

\section{Acknowledgements}

The authors would like to acknowledge Cabildo de Tenerife (permit number 18297), Cabildo de La Gomera (3102), Cabildo La Palma (2015005976) and Gobierno de Canarias (260209, 2015/939) for providing permits for fieldwork collections in Canary Islands. In addition, we would like to thank Juan Antonio Devesa Alcaraz (University of Córdoba) and Manuel de la Estrella (Royal Botanic Gardens Kew) for assisting with permits for collections in Andalusia. Fieldwork collections were performed with the help of Rachael Graham, Arnoldo Santos-Guerra, Giancarlo Torre, Magui Olangua-Corral and Miguel Menezes de Sequeira. Members of the Chapman lab at the University of Southampton and the biogeography discussion group at the Royal Botanic Gardens Kew provided instructive comments on the earlier drafts of the manuscript. We would like to thank Marcelino del Arco for sharing shape files for the vegetation of the Canary Islands. We would also like to acknowledge the use of the IRIDIS High-Performance Computing Facility, and associated support services at the University of Southampton, in the completion of this work. Finally, we would like to thank the anonymous reviewers for their feedback on our initial submission. This work was funded by an NHMUniversity of Southampton PhD studentship to OW.

\section{Author contributions}

Oliver White (OW), Mark Chapman (MCh) and Mark Carine (MCa) designed the study; OW, Alfredo Reyes-Betancort (AR-B) and MCa planned and undertook fieldwork; OW and MCh led the data analysis; all authors contributed to the interpretation of results; OW wrote the first draft of the manuscript; all co-authors contributed to the preparation of the final manuscript.

\section{Data availability statement}

Raw demultiplexed GBS sequence data used in this study are available from NCBI GenBank (BioProject ID: PRJNA664547) and assembled datasets are available upon request.

\section{References}

Allan GJ, Francisco-Ortega J, Santos-Guerra A, Boerner E, Zimmer EA. 2004. Molecular phylogenetic evidence for the geographic origin and classification of Canary Island Lotus (Fabaceae: Loteae). Molecular Phylogenetics and Evolution 32: 123-138. 
del Arco Aguilar MJ, Rodríguez-Delgado O. 2018. Vegetation of the Canary Islands (MJA Werger, Ed.). Cham: Spinger.

Baird NA, Etter PD, Atwood TS, Currey MC, Shiver AL, Zachary A, Selker EU, Cresko WA, Johnson EA. 2008. Rapid SNP discovery and genetic mapping using sequenced RAD markers. PLoS Genetics 3: 1-7.

Baldwin BG, Crawford DJ, Francisco-Ortega J, Kim S-C, Stuessy TF. 1999. Molecular phylogenetic insights on the origin and evolution of oceanic island plants. In: Soltis DE, Soltis PS, Doyle JJ, eds. Molecular systematics of plants II. DNA sequencing. Boston, MA: Kluwer Academic Press, 410-441.

Baldwin BG, Sanderson MJ. 1998. Age and rate of diversification of the Hawaiian silversword alliance (Compositae). Proceedings of the National Academy of Sciences 95: 9402-9406.

Barber JC, Finch CC, Francisco-Ortega J, Santos-Guerra A, Jansen RK. 2007. Hybridization in Macaronesian Sideritis (Lamiaceae): Evidence from incongruence of multiple independent nuclear and chloroplast sequence datasets. Taxon 56: 74-88.

Barrier M, Baldwin BG, Robichaux RH, Purugganan MD. 1999. Interspecific hybrid ancestry of a plant adaptive radiation: allopolyploidy of the Hawaiian silversword alliance (Asteraceae) inferred from floral homeotic gene duplications. Molecular biology and evolution 16: 1105-1113.

Borgen L. 1976. Analysis of a hybrid swarm between Argyranthemum adauctum and A. filifolium in the Canary islands. Norwegian Journal of Botany 23: 121-137.

Bramwell D. 2011. Introduction: islands and plants. In: Bramwell D, Caujapé-Castells J, eds. The Biology of Island Floras. Cambridge: Cambridge University Press, 1-10.

Brochmann C. 1984. Hybridization and distribution of Argyranthemum coronopifolium (Asteraceae, Anthemideae) in the Canary Islands. Nordic Journal of Botany 4: 729-736.

Brochmann C. 1987. Evaluation of some methods for hybrid analysis, exemplified by hybridisation in Argyranthemum. Nordic Journal of Botany 7: 609-630.

Brochmann C, Borgen L, Stabbetorp OE. 2000. Multiple diploid hybrid speciation of the Canary Island endemic Argyranthemum sundingii (Asteraceae). Plant Systematics and Evolution 220: 77-92.

\section{Caujapé-Castells J, Tye A, Crawford DJ, Santos-Guerra A, Sakai A, Beaver K, Lobin W, Vincent} Florens FB, Moura M, Jardim R, et al. 2010. Conservation of oceanic island floras: Present and future global challenges. Perspectives in Plant Ecology, Evolution and Systematics 12: 107-129. 
564 Curto M, Schachtler C, Puppo P, Meimberg H. 2017. Using a new RAD-sequencing approach to study the evolution of Micromeria in the Canary Islands. Molecular Phylogenetics and Evolution 119: 160169.

Dupin J, Matzke NJ, Särkinen T, Knapp S, Olmstead RG, Bohs L, Smith SD. 2017. Bayesian estimation of the global biogeographical history of the Solanaceae. Journal of Biogeography 44: 887-899.

Eaton D, Ree RH. 2013. Inferring phylogeny and introgression using RADseq data: an example from flowering plants (Pedicularis: Orobanchaceae). Systematic Biology 62: 689-706.

Elshire RJ, Glaubitz JC, Sun Q, Poland JA, Kawamoto K, Buckler ES, Mitchell SE. 2011. A robust, simple genotyping-by-sequencing (GBS) approach for high diversity species. PLoS ONE 6: 1-10. ESRI. 2019. ArcGIS Desktop: Release 10.7. Redlands CA: Environmental Systems Research Institute.

Fjellheim S, Jørgensen MH, Kjos M, Borgen L. 2009. A molecular study of hybridization and homoploid hybrid speciation in Argyranthemum (Asteraceae) on Tenerife, the Canary Islands. Botanical Journal of the Linnean Society 159: 19-31.

Francisco-Ortega J, Crawford DJ, Santos-Guerra A, Carvalho JA. 1996a. Isozyme differenctiation in the endemic genus Argyranthemum (Asteraceae: Anthemideae) in the Macaronesian Islands. Plant Systematics and Evolution 202: 137-152.

Francisco-Ortega J, Crawford DJ, Santos-Guerra A, Jansen RK. 1997a. Origin and Evolution of Argyranthemum (Asteraceae: Anthemideae) in Macaronesia. In: Givnish TJ, Sytsma KJ, eds. In Molecular Evolution and Adaptive Radiation. Cambridge University Press, 407-432. Mediterranean and Macronesian genera of the subtribe Chrysantheminae (Asteraceae). American Journal of Botany 82: 1321-1328. Francisco-Ortega J, Fuertes-Aguilar J, Kim SC, Santos-Guerra A, Crawford DJ, Jansen RK. 2002. Phylogeny of the Macaronesian endemic Crambe section Dendrocrambe (Brassicaceae) based on internal transcribed spacer sequences of nuclear ribosomal DNA. American Journal of Botany 89 : 1984-1990. intergeneric relationships of the macaronesian endemic genus Argyranthemum (Asteraceae). 
Francisco-Ortega J, Jansen RK, Santos-Guerra A. 1996b. Chloroplast DNA evidence of colonization, adaptive radiation, and hybridization in the evolution of the Macaronesian flora. Proceedings of the National Academy of Sciences of the United States of America 93: 4085-4090.

Francisco-Ortega J, Santos-Guerra A, Hines A, Robert K. 1997b. Molecular evidence for a Mediterranean origin of the Macaronesian endemic genus Argyranthemum (Asteraceae). American Journal of Botany 84: 1595-1613.

Francisco-Ortega J, Santos-Guerra A, Kim SC, Crawford DJ. 2000. Plant genetic diversity in the Canary Islands: A conservation perspective. American Journal of Botany 87: 909-919.

Francisco-Ortega J, Santos-Guerra A, Mesa-Coello R, Gonzalez-Feria E, Crawford DJ. 1996c. Genetic resource conservation of the endemic genus Argyranthemum Sch. Bip. (Asteraceae: Anthemideae) in the Macaronesian Islands. Genetic Resources and Crop Evolution 43: 33-39.

Goodson BE, Santos-guerra A, Jansen RK, Goodson E, Jansen K. 2006. Molecular systematics of Descurainia (Brassicaceae) in the Canary Islands: Biogeographic and taxonomic implications. Taxon 55: 671-682.

GruenstaeudI M, Carstens BC, Santos-Guerra A, Jansen RK. 2017. Statistical hybrid detection and the inference of ancestral distribution areas in Tolpis (Asteraceae). Biological Journal of the Linnean Society 121: 133-149.

GruenstaeudI M, Santos-Guerra A, Jansen RK. 2013. Phylogenetic analyses of Tolpis Adans. (Asteraceae) reveal patterns of adaptive radiation, multiple colonization and interspecific hybridization. Cladistics 29: 416-434.

Han F, Lamichhaney S, Grant BR, Grant RP, Andersson L, Webster MT. 2017. Gene flow, ancient polymorphism, and ecological adaptation shape the genomic landscape of divergence among Darwin's finches. Genome Research 27: 1004-1015.

Humphries CJ. 1973. A Taxonomic study of the genus Argyranthemum Webb Ex Sch. BIP. PhD thesis, The University of Reading, Berkshire, UK.

Humphries CJ. 1976. A Revision of the Macaronesian Genus Argyranthemum Webb Ex Schultz BIP. (Compositae-Anthemideae). Bulletin of the British Museum Natural History 5: 145-240. 
Jones KE, Reyes-Betancort JA, Hiscock SJ, Carine MA. 2014. Allopatric diversification, multiple habitat shifts, and hybridization in the evolution of Pericallis (Asteraceae), a Macaronesian endemic genus. American Journal of Botany 101: 637-651.

Kim SC, McGowen MR, Lubinsky P, Barber JC, Mort ME, Santos-Guerra A. 2008. Timing and tempo of early and successive adaptive radiations in Macaronesia. PLOS ONE 3: 1-7.

Kozlov AM, Darriba D, Flouri T, Morel B, Stamatakis A, Wren J. 2019. RAxML-NG: A fast, scalable and user-friendly tool for maximum likelihood phylogenetic inference. Bioinformatics 35: 4453-4455.

\section{Lamichhaney S, Han F, Berglund J, Wang C, Almén MS, Webster MT, Grant BR, Grant PR,} Andersson L. 2016. A beak size locus in Darwin's finches facilitated character displacement during a drought. Science 352: 470-474.

Lamichhaney S, Han F, Webster MT, Andersson L, Grant BR, Grant PR. 2017. Rapid hybrid speciation in Darwin's finches. Sience 4593: 224-228.

Landis MJ, Matzke NJ, Moore BR, Huelsenbeck JP. 2013. Bayesian analysis of biogeography when the number of areas is large. Systematic Biology 62: 789-804.

Lee C, Kim SC, Lundy K, Santos-Guerra A. 2005. Chloroplast DNA phylogeny of the woody Sonchus alliance (Asteraceae: Sonchinae) in the Macaronesian Islands. American Journal of Botany 92: 20722085.

Litsios G, Pearman PB, Lanterbecq D, Tolou N, Salamin N. 2014. The radiation of the clownfishes has two geographical replicates. Journal of Biogeography 41: 2140-2149.

Losos JB, Jackman TR, Larson A, Queiroz K de, Rodríguez-Schettino L. 1998. Contingency and determinismin replicated adaptative radiations of island lizards. Science 279: 2115-2118.

Marques DA, Meier JI, Seehausen O. 2019. A combinatorial view on speciation and adaptive radiation. Trends in Ecology \& Evolution 34: 531-544.

Matzke NJ. 2014. Model selection in historical biogeography reveals that founder-event speciation is a crucial process in island clades. Systematic Biology 63: 951-970.

Matzke NJ. 2020. Stochastic mapping under biogeographical models. http://phylo.wikidot.com/biogeobears\#stochastic_mapping [accessed 01 April 2020]. 
McVay JD, Hipp AL, Manos PS. 2017. A genetic legacy of introgression confounds phylogeny and biogeography in oaks. Proceedings of the Royal Society of London B 284: 20170300.

Meier JI, Marques DA, Mwaiko S, Wagner CE, Excoffier L, Seehausen O. 2017. Ancient hybridization fuels rapid cichlid fish adaptive radiations. Nature Communications 8: 14363.

Mort ME, Crawford DJ, Kelly JK, Santos-Guerra A, Menezes de Sequeira M, Moura M, CaujapeCastells J. 2015. Multiplexed-shotgun-genotyping data resolve phylogeny within a very recently derived insular lineage. American Journal of Botany 102: 634-641.

Mort M, Soltis DE, Soltis PS, Francisco-Ortega J. 2002. Phylogenetics and evolution of the Macaronesian clade of Crassulaceae inferred from nuclear and chloroplast sequence data. Systematic Botany 27: 271-288.

Oberprieler C, Himmelreich S, Vogt R. 2007. A new subtribal classification of the tribe Anthemideae. Willdenowia 37: 89-114.

Paun O, Turner B, Trucchi E, Munzinger J, Chase MW, Samuel R. 2016. Processes driving the adaptive radiation of a tropical tree (Diospyros, Ebenaceae) in New Caledonia, a biodiversity hotspot. Systematic Biology 65: 212-227.

Pérez-Escobar OA, Chomicki G, Condamine FL, Karremans AP, Bogarín D, Matzke NJ, Silvestro D, Antonelli A. 2017. Recent origin and rapid speciation of Neotropical orchids in the world's richest plant biodiversity hotspot. New Phytologist 215: 891-905.

Puppo P, Curto M, Gusmão-Guedes J, Cochofel J, Pérez de Paz PL, Bräuchler C, Meimberg H. 2015. Molecular phylogenetics of Micromeria (Lamiaceae) in the Canary Islands, diversification and interisland colonization patterns inferred from nuclear genes. Molecular Phylogenetics and Evolution 89: $160-170$.

R Core team. 2020. R (v3.6.3): A language and environment for statistical computing. R Foundation for Statistical Computing, Vienna, Austria.

Rambaut A, Drummond AJ, Xie D, Baele G, Suchard MA. 2018. Posterior summarization in Bayesian phylogenetics using Tracer 1.7. Systematic Biology 67: 901-904.

Ree RH, Sanmartín I. 2018. Conceptual and statistical problems with the DEC+J model of founderevent speciation and its comparison with DEC via model selection. Journal of Biogeography 45: 741- 

749.

Ree RH, Smith SA. 2008. Maximum likelihood inference of geographic range evolution by dispersal, local extinction, and cladogenesis. Systematic Biology 57: 4-14.

Rees DJ, Emerson BC, Oromí P, Hewitt GM. 2001. The diversification of the genus Nesotes (Coleoptera: Tenebrionidae) in the Canary Islands: Evidence from mtDNA. Molecular Phylogenetics and Evolution 21: 321-326.

dos Reis M, Donoghue PCJ, Yang Z. 2016. Bayesian molecular clock dating of species divergences in the genomics era. Nature Reviews Genetics 17: 71-80.

Ronquist F. 1997. Dispersal-Vicariance Analysis: A New Approach to the Quantification of Historical Biogeography. Systematic Biology 46: 195-203.

Ronquist F, Teslenko M, Van Der Mark P, Ayres DL, Darling A, Höhna S, Larget B, Liu L, Suchard MA, Huelsenbeck JP. 2012. Mrbayes 3.2: Efficient bayesian phylogenetic inference and model choice across a large model space. Systematic Biology 61: 539-542.

Schaefer H, Moura M, Belo Maciel MG, Silva L, Rumsey FJ, Carine MA. 2011. The Linnean shortfall in oceanic island biogeography: A case study in the Azores. Journal of Biogeography 38: 1345-1355. Amazonian and Atlantic forest clades of Neotropical lianas (Amphilophium, Bignonieae) inferred from plastid genomic data. Molecular Phylogenetics and Evolution 133: 92-106. phylogenetics of the Macaronesian-endemic genus Bystropogon (Lamiaceae): Palaeo-islands, ecological shifts and interisland colonizations. Molecular Ecology 14: 1177-1189. radiation of Cheirolophus (Asteraceae, Cardueae) in Macaronesia. BMC Evolutionary Biology 14: 118. repeat marker development for three macaronesian endemic plant species. Applications in Plant Sciences 4: 1600050. speciation events in the Macaronesian endemic genus Argyranthemum. Molecular Ecology 27: 

4856-4874.

704 Yang Z. 2007. PAML 4: Phylogenetic analysis by maximum likelihood. Molecular Biology and 705 Evolution 24: 1586-1591.

706 Yu G, Smith DK, Zhu H, Guan Y, Lam TTY. 2017. ggtree: An R package for visualization and 707 annotation of phylogenetic trees with their covariates and other associated data. Methods in 708 Ecology and Evolution 8: 28-36. 


\section{Supporting Information Figures}

Fig. S 1 Principal Component Analysis (PCA) for each dataset.

Fig. S 2 Delta K and STRUCTURE plots for $\mathrm{K}$ one to 10 for datasets assembled.

Fig. 3 Trace files for MrBayes analysis for each dataset.

Fig. S 4 Number of occurrence records for each vegetation type for all taxa in Argyranthemum.

Fig. S 5 Number of habitat types scored against the threshold used for filtering potentially erroneous data for all taxa in Argyranthemum.

Fig. S 6 Clades within islands used for D-statistics.

Fig. 57 Number of reads for each sample following the filtering step of the ipyrad pipeline.

Fig. 5 \& Maximum likelihood tree generated using RAxML-NG for the dataset based on a clustering threshold of $80 \%$ and minimum sample number of 30 .

Fig. S 9 Maximum likelihood tree generated using RAxML-NG for the dataset based on a clustering threshold of $80 \%$ and minimum sample number of 38 .

Fig. S 10 Maximum likelihood tree generated using RAxML-NG for the dataset based on a clustering threshold of $85 \%$ and minimum sample number of 30 .

Fig. S 11 Maximum likelihood tree generated using RAxML-NG for the dataset based on a clustering threshold of $85 \%$ and minimum sample number of 38 .

Fig. S 12 Maximum likelihood tree generated using RAxML-NG for the dataset based on a clustering threshold of $90 \%$ and minimum sample number of 30 .

Fig. S 13 Maximum likelihood tree generated using RAxML-NG for the dataset based on a clustering threshold of $90 \%$ and minimum sample number of 38 .

Fig. S 14 Bayesian inference tree generated using MrBayes for the dataset based on a clustering threshold of $80 \%$ and minimum sample number of 30 .

Fig. S 15 Bayesian inference tree generated using MrBayes for the dataset based on a clustering threshold of $80 \%$ and minimum sample number of 38 .

Fig. S 16 Bayesian inference tree generated using MrBayes for the dataset based on a clustering threshold of $85 \%$ and minimum sample number of 30 .

Fig. S 17 Bayesian inference tree generated using MrBayes for the dataset based on a clustering threshold of $85 \%$ and minimum sample number of 38 .

Fig. S 18 Bayesian inference tree generated using MrBayes for the dataset based on a clustering threshold of $90 \%$ and minimum sample number of 30 . 
Fig. S 19 Bayesian inference tree generated using MrBayes for the dataset based on a clustering threshold of $90 \%$ and minimum sample number of 38.

Fig. S 20 Time calibrated species tree of Argyranthemum.

Fig. S 21 Convergence of node date times across two independent MCMCTree analyses.

Fig. S 22 Ancestral range estimation for geography (left) and habitat (right) performed in BioGeoBEARS using DIVALIKE and BAYAREALIKE models respectively.

Fig. S 23 Morphology of $A$. callichrysum, A. broussonetii subsp. gomerensis and A. broussonetii subsp. broussonetii.

\section{Supporting Information Tables}

Table S 1 Summary of ipyrad parameters used for each assembly.

Table S 2 Cluster classification for each dataset identified by mclust.

Table S 3 AICc ranked substitution models for each dataset.

Table S 4 Summary statistics of MrBayes chain convergence.

Table S 5 Potential vegetation codes identified across georeferenced localities.

Table S 6 Best supported biogeographic model with varying thresholds for filtering potentially erroneous data.

Table S 7 Biogeographic areas identified for all taxa in Argyranthemum.

Table S 8 Summary of the 183 partitioned D-statistics performed.

Table S 9 Summary statistics for the samples used in our GBS assemblies generated using ipyrad.

Table S 10 Summary statistics for each ipyrad assembly.

Table S 11 Proportion of missing data across samples used in the phylogenetic analysis.

\section{Supporting Information Methods}

Methods S 1 Genetic clustering using PCA and STRUCTURE.

Methods S 2 Jupyter notebook of D-statistics performed. 


\section{Tables}

Table 1 Leaf sampling for genotyping-by-sequencing (GBS) with taxa, collection reference, location, leaf and representative voucher specimen barcodes. Barcodes are for leaf and voucher specimens deposited at the Natural History Museum London (BM).

\begin{tabular}{|c|c|c|c|c|}
\hline Taxa & Collection & Location & Leaf & Voucher \\
\hline G. coronaria & White et al. 797 & Andalucía, province of Cádiz & BM001092800 & BM013407815 \\
\hline G. segetum & White et al. 796 & Andalucía, province of Cádiz & BM001092799 & BM013407814 \\
\hline A. adauctum subsp. adauctum & White et al. 120 & Between La Laguna and Las Cañadas del Teide & BM010765622 & BM000828632 \\
\hline A. adauctum subsp. adauctum & White et al. 135 & Valle de la Orotova, TF-21 & BM010765636 & BM000828618 \\
\hline A. adauctum subsp. canariense & White et al. 363 & GC-600 South of Presa de la Siberia & BM010765864 & BM000828531 \\
\hline A. adauctum subsp. canariense & White et al. 366 & South East of Presa de la Siberia & BM010765867 & BM000828528 \\
\hline A. adauctum subsp. dugourii & White et al. 163 & Off-road track North East of Vilaflor & BM010765664 & BM000828592 \\
\hline A. adauctum subsp. dugourii & White et al. 166 & Off-road track North East of Vilaflor & BM010765667 & BM000828589 \\
\hline A. adauctum subsp. erythrocarpon & White.et al. 43 & HI-1 between El Brezal and El Salvador & BM010765545 & BM000828709 \\
\hline A. adauctum subsp. erythrocarpon & White et al. 44 & HI-1 between El Brezal and El Salvador & BM010765546 & BM000828708 \\
\hline A. adauctum subsp. gracile & White et al. 356 & GC- 60 between La Plata and Agualatente & BM010765857 & BM000828534 \\
\hline A. adauctum subsp. gracile & White.et al. 360 & GC-60 South of Risco las Candelillas & BM010765861 & BM000828533* \\
\hline A. adauctum subsp. jacobaeifolium & White et al. 368 & South of Valsendero & BM010765869 & BM000828526 \\
\hline A. adauctum subsp. jacobaeifolium ${ }^{1}$ & White et al. 370 & Near to La Laguna & BM010765871 & BM000828524 \\
\hline A. adauctum subsp. palmensis & White et al. 58 & Walk from Los Tilos to Marcos y Corderos & BM010765560 & BM000828694 \\
\hline A. adauctum subsp. palmensis & White et al. 62 & Walk from Los Tilos to Marcos y Corderos & BM010765564 & BM000828690 \\
\hline A. broussonetii subsp. broussonetii & White et al. 157 & Roques del Fraile & BM010765658 & BM000828598 \\
\hline A. broussonetii subsp. broussonetii & White et al. 494 & La Cumbrilla, Anaga & BM010765995 & BM000828683* \\
\hline A. broussonetii subsp. broussonetii & White et al. 552 & Path to Mesa del Sabinal, Anaga & BM010766053 & BM000828674* \\
\hline A. broussonetii subsp. broussonetii & White et al. 664 & Chamorga, Anaga & BM010766164 & BM000828483* \\
\hline A. broussonetii subsp. broussonetii & White et al. 674 & Chamorga, Anaga & BM010766174 & BM000828482* \\
\hline
\end{tabular}


A. broussonetii subsp. broussonetii

A. broussonetii subsp. broussonetii

A. broussonetii subsp. broussonetii

A. broussonetii subsp. gomerensis

A. broussonetii subsp. gomerensis

A. callichrysum

A. callichrysum

A. coronopifolium

A. coronopifolium

A. dissectum

A. dissectum

A. escarrei

A. escarrei

A. filifolium

A. filifolium

A. foeniculaceum

A. foeniculaceum

A. frutescens subsp. canariae

A. frutescens subsp. canariae

A. frutescens subsp. foeniculaceum

A. frutescens subsp. foeniculaceum

A. frutescens subsp. frutescens

A. frutescens subsp. frutescens

A. frutescens subsp. frutescens

A. frutescens subsp. frutescens

A. frutescens subsp. gracilescens

A. frutescens subsp. gracilescens

A. frutescens subsp. parviflorum
White et al. 719 White et al. 749

White et al. 768

White et al. 110

White et al. 112

White et al. 95

White et al. 97

White et al. 80

Graham et al. 107b

Graham et al. 13

Graham et al. 19

White et al. 335

White et al. 338

White et al. 344

White et al. 346

White et al. 142

White et al. 144

White et al. 319

White et al. 320

White et al. 107

White et al. 116

White et al. 567

White et al. 585

White et al. 611

White et al. 620

White et al. 177

White et al. 179

White et al. 101
Las Casas de la Cumbre, Anaga

Barranco de Valle Crispín, Anaga

Barranco de Valle Crispín, Anaga

CV-5 between Las Rosas and La Palmita

South of La Palmita

Valley below TF-713 in Barranco de la Guancha

Roque de Agando

Chinamada, Anaga

Anaga, Afur Roque Marrubial

Fajã dos Padres above cable car station

By tunnel entrance near Fajã da Ovelha

GC-200 between La Playa and Tirma

GC-200 near Degollada de la Aldea

GC-200 North of Mogán

Barranco de Fataga

TF-436 between Las Portelas and Masca

TF-436 between Masca and Santiago del Teide

North of La Atalaya

North of La Atalaya

TF-712 through Barranco del Valle

\section{Agulo}

Maria Jiménez, Anaga

Maria Jiménez, Anaga

Barranco del Cercado de Andrés, Anaga

Barranco del Cercado de Andrés, Anaga

TF-625 above Porís de Abona

Road near to Arafo

Calle la Lajita North of Aeropuerto de GO

$\begin{array}{ll}\text { BM010766218 } & \text { BM000828476* } \\ \text { BM010766248 } & \text { BM000828668* } \\ \text { BM010766267 } & \text { BM000828667* } \\ \text { BM010765612 } & \text { BM000828642 } \\ \text { BM010765614 } & \text { BM000828640 } \\ \text { BM010765597 } & \text { BM000828657 } \\ \text { BM010765599 } & \text { BM000828655 } \\ \text { BM010765582 } & \text { BM000828672 } \\ \text { BM001092356 } & \text { BM000828856 } \\ \text { BM001092072 } & \text { BM000828763 } \\ \text { BM001092082 } & \text { BM000828769 } \\ \text { BM010765836 } & \text { BM000828542 } \\ \text { BM010765839 } & \text { BM000828542* } \\ \text { BM010765845 } & \text { BM000828540 } \\ \text { BM010765847 } & \text { BM000828538 } \\ \text { BM010765643 } & \text { BM000828611 } \\ \text { BM010765645 } & \text { BM000828609 } \\ \text { NA } & \text { BM000828553 } \\ \text { NA } & \text { BM000828552 } \\ \text { BM010765609 } & \text { BM000828645 } \\ \text { BM010765618 } & \text { BM000828636 } \\ \text { BM010766068 } & \text { BM000828558* } \\ \text { BM010766086 } & \text { BM000828557* } \\ \text { BM010766112 } & \text { BM000828514* } \\ \text { BM010766120 } & \text { BM000828513* } \\ \text { BM010765678 } & \text { BM000828578 } \\ \text { BM010765680 } & \text { BM000828576 } \\ \text { BM010765603 } & \text { BM000828651 }\end{array}$


A. frutescens subsp. parviflorum

A. frutescens subsp. pumilum ${ }^{1}$

A. frutescens subsp. pumilum ${ }^{1}$

A. frutescens subsp. succulentum

A. frutescens subsp. succulentum

A. frutescens subsp. succulentum

A. frutescens subsp. succulentum

A. gracile

A. gracile

A. haematomma

A. haouarytheum

A. haouarytheum

A. hierrense

A. hierrense

A. lidii

A. lidii

A. maderense

A. maderense

A. pinnatifidum subsp. montanum

A. pinnatifidum subsp. pinnatifidum

A. pinnatifidum subsp. succulentum

A. sventenii

A. sventenii

A. tenerifae ${ }^{1}$

A. tenerifae

A. tenerifae

A. tenerifae ${ }^{1}$

A. thalassophilum
White et al. 92 White et al. 326 White et al. 329 White et al. 229 White et al. 234 White et al. 242 White et al. 244 White et al. 169 White et al. 172 Graham et al. 15 White et al. 56 White et al. 57 White et al. 38 White et al. 47 White et al. 321 White et al. 325

White et al. 775

White et al. 777

Graham et al. 25

Graham et al. 38

Graham et al. 3

Graham et al. 119a

Graham et al. 119b

White et al. 131

White et al. 159

White et al. 160

White et al. 564

Filipe Silva
Barranco del Revolcadero above San Sebastián Alongside GC-200, North of Laja del Risco Overlooking Laja del Risco

Between Almáciga and Roque Bermejo, Anaga Between Almáciga and Roque Bermejo, Anaga Roque Bermejo

Roque Bermejo

TF-38 above Chío and Guía de Isora

TF-82 above Tijoco Bajo

Path between Prazeres and Paul do Mar

LP-2 approximately two km North of El Charco

Walk below Volcán de San Antonio

HI-50 East of Sabinosa

HI-15 approx. 1km North of Villa de Valverde

Amagro

Amagro

Haría, above Barranco de Temisa

Haría, Vueltas de Malpaso

On path from Pico do Arieiro to Pico Ruivo

West of Encumeada Just after third road tunnel

Ponta de São Lourenço

By main road to Restinga

By main road to Restinga

TF-24 below to Observatorio del Teide

TF-24, Cañadas del Teide

TF-24, Cañadas del Teide

Cañadas - walk to Refuge

Selvagem Pequena

$\begin{array}{ll}\text { BM010765594 } & \text { BM000828660 } \\ \text { BM010765827 } & \text { BM000828551 } \\ \text { BM010765830 } & \text { BM000828548 } \\ \text { BM010765730 } & \text { BM000828575* } \\ \text { BM010765735 } & \text { BM000828574* } \\ \text { BM010765743 } & \text { BM000828732* } \\ \text { BM010765745 } & \text { BM000828731* } \\ \text { BM010765670 } & \text { BM000828586 } \\ \text { BM010765673 } & \text { BM000828583 } \\ \text { BM000828765 } & \text { BM001092077 } \\ \text { BM010765558 } & \text { BM000828696 } \\ \text { BM010765559 } & \text { BM000828695 } \\ \text { BM010765540 } & \text { BM000828714 } \\ \text { BM010765549 } & \text { BM000828705 } \\ \text { BM010765822 } & \text { BM000828547* } \\ \text { BM010765826 } & \text { BM000828546* } \\ \text { BM010766274 } & \text { BM000828473 } \\ \text { BM010766276 } & \text { BM000828471 } \\ \text { BM001092094 } & \text { BM000828775 } \\ \text { BM001092116 } & \text { BM000828788 } \\ \text { BM001092048 } & \text { BM000828753 } \\ \text { BM001092381 } & \text { BM000828870 } \\ \text { BM001092382 } & \text { BM000828870 } \\ \text { BM010765632 } & \text { BM000828622 } \\ \text { BM010765660 } & \text { BM000828596 } \\ \text { BM010765661 } & \text { BM000828595 } \\ \text { BM010766065 } & \text { BM000828596* } \\ \text { NA } & \text { UMad s/n }\end{array}$




\begin{tabular}{|c|c|c|c|c|}
\hline A. vincentii & White et al. 123 & Barranco de la Gota near to TF-523, above Arafo & BM010765625 & BM000828629 \\
\hline A. vincentii & White et al. 125 & Barranco de la Gota near to TF-523, above Arafo & BM010765627 & BM000828627 \\
\hline A. webbii & White et al. 49 & road near Lomo los Machines & BM010765551 & BM000828703 \\
\hline A. webbii & White et al. 50 & LP-1 between Llano Negro and Roque del Faro & BM010765552 & BM000828702 \\
\hline A. winteri ${ }^{1}$ & White et al. 794 & Pájara, Jandía, Pico de La Zarza & BM001092793 & NA \\
\hline A. winteri & White et al. 795 & Pájara, Jandía, Pico de La Zarza & BM001092794 & NA \\
\hline
\end{tabular}

${ }^{1}$ Samples were removed for having less than 500,000 filtered GBS reads

* If a voucher for this leaf sample is not available a representative voucher from the same population is given

White et al. refers to collection made by O. White, M. Carine, A. Reyes-Betancort A. Santos-Guerra, G. Torre and M. Olangua-Corral

Graham et al. refers to collections made by R. Graham, M. Carine, M. Menezes de Sequeira 
Table 2 Comparison of ancestral range estimation models DEC, DIVALIKE and BAYAREALIKE as implemented in BioGeoBEARS for geography and habitats. The best scoring models based on log-likelihood (LnI) and corrected Akaike information criterion weight (AICc wt) are highlighted in bold. Other parameters include rate of dispersal (d) and rate of extinction (e).

\begin{tabular}{|c|c|c|c|c|c|c|c|}
\hline & & $\mathrm{LnL}$ & numparams & d & e & $\mathrm{AlCc}$ & AlCc_wt \\
\hline \multirow[t]{3}{*}{ Geography } & DEC & -71.52 & 2 & 0.021 & 0.034 & 147.4 & $1.20 \times 10^{-10}$ \\
\hline & DIVALIKE & -64.34 & 2 & 0.022 & $1.00 \times 10^{-12}$ & 133.0 & $1.50 \times 10^{-07}$ \\
\hline & BAYAREALIKE & -90.39 & 2 & 0.022 & 0.440 & 185.1 & $7.50 \times 10^{-19}$ \\
\hline \multirow[t]{3}{*}{ Habitats } & DEC & -128.50 & 2 & 0.170 & 0.043 & 261.3 & $6.20 \times 10^{-8}$ \\
\hline & DIVALIKE & -129.00 & 2 & 0.180 & $1.00 \times 10^{-12}$ & 262.2 & $3.80 \times 10^{-8}$ \\
\hline & BAYAREALIKE & -112.10 & 2 & 0.025 & 0.430 & 228.6 & 0.76 \\
\hline
\end{tabular}

Table 3 Summary of biogeographic events identified using BioGeoBEARS across 50 biogeographic stochastic maps for geography (DIVALIKE) and habitats (BAYAREALIKE). Mean counts for each event type are shown along with standard deviations and percentage of overall events. In the context of the oceanic islands, we interpret vicariance as inter-island allopatric speciation for geography and habitat shifts for habitat data.

\begin{tabular}{|c|c|c|c|c|c|c|c|}
\hline & & \multicolumn{3}{|c|}{ Geography } & \multicolumn{3}{|c|}{ Habitat } \\
\hline & & Mean & sd & pct. & Mean & sd & pct. \\
\hline \multirow[t]{2}{*}{ Anagenetic } & Range expansion & 10.06 & 0.24 & $20.51 \%$ & 7.76 & 2.41 & $7.30 \%$ \\
\hline & Range contraction & 0.00 & 0.00 & $0.00 \%$ & 59.50 & 4.86 & $55.99 \%$ \\
\hline \multirow[t]{3}{*}{ Cladogenetic } & Intra-range; narrow & 27.78 & 0.51 & $56.62 \%$ & 39.00 & 0.00 & $36.70 \%$ \\
\hline & Intra-range; subset & 0.00 & 0.00 & $0.00 \%$ & 0.00 & 0.00 & $0.00 \%$ \\
\hline & Vicariance & 11.22 & 0.51 & $22.87 \%$ & 0.00 & 0.00 & $0.00 \%$ \\
\hline Total & & 49.06 & & $100.00 \%$ & 106.26 & & $100.00 \%$ \\
\hline
\end{tabular}


Table 4 Summary of D-statistics performed between clades from the same island (tests 1-29) and between clades of non-monophyletic multi-island endemic taxa (tests 3033). For each test performed, the taxa at positions P1, P2, and P3 are shown, together with the D-statistic, mean bootstrap value, bootstrap standard deviation, Z score, $A B B A$ and $B A B A$ frequencies and number of loci used in the test. D-statistics significant at the 0.01 level are indicated with an asterisk. D-statistics that were also significant based on partitioned D-statistics are highlighted in bold.

\begin{tabular}{|c|c|c|c|c|c|c|c|c|c|c|}
\hline $\mathrm{n}$ & P1 & P2 & P3 & D & bootmean & bootstd & Z & ABBA & BABA & nloci \\
\hline 1 & $\begin{array}{l}\text { A. callichrysum, } \\
\text { A. broussonetii subsp. gomerensis } \\
\text { (La Gomera) }\end{array}$ & $\begin{array}{l}\text { A. sventenii, } \\
\text { A. hierrense } \\
\text { (El Hierro) }\end{array}$ & $\begin{array}{l}\text { A. adauctum subsp. erythrocarpon } \\
\text { (El Hierro) }\end{array}$ & $0.33 *$ & 0.33 & 0.05 & 6.92 & 237.34 & 120.35 & 3100 \\
\hline 2 & $\begin{array}{l}\text { A. callichrysum, } \\
\text { A. broussonetii subsp. gomerensis } \\
\text { (La Gomera) }\end{array}$ & $\begin{array}{l}\text { A. haouarytheum } \\
\text { (La Palma) }\end{array}$ & $\begin{array}{l}\text { A. adauctum subsp. palmensis } \\
\text { (La Palma) }\end{array}$ & 0.09 & 0.09 & 0.05 & 1.73 & 165.34 & 137.25 & 2877 \\
\hline 3 & $\begin{array}{l}\text { A. callichrysum, } \\
\text { A. broussonetii subsp. gomerensis } \\
\text { (La Gomera) }\end{array}$ & $\begin{array}{l}\text { A. webbii } \\
\text { (La Palma) }\end{array}$ & $\begin{array}{l}\text { A. adauctum subsp. palmensis } \\
\text { (La Palma) }\end{array}$ & $0.20 *$ & 0.20 & 0.05 & 4.01 & 169.81 & 114.18 & 3038 \\
\hline 4 & $\begin{array}{l}\text { A. callichrysum, } \\
\text { A. broussonetii subsp. gomerensis } \\
\text { (La Gomera) }\end{array}$ & $\begin{array}{l}\text { A. webbii } \\
\text { (La Palma) }\end{array}$ & $\begin{array}{l}\text { A. haouarytheum } \\
\text { (La Palma) }\end{array}$ & 0.20 * & 0.21 & 0.05 & 3.94 & 148.08 & 98.02 & 2720 \\
\hline 5 & $\begin{array}{l}\text { A. sventenii, } \\
\text { A. hierrense } \\
\text { (El Hierro) }\end{array}$ & $\begin{array}{l}\text { A. callichrysum, } \\
\text { A. broussonetii subsp. gomerensis } \\
\text { (La Gomera) }\end{array}$ & $\begin{array}{l}\text { A. frutescens subsp. parviforum, } \\
\text { A. frutescens subsp. foeniculaceum } \\
\text { (La Gomera) }\end{array}$ & 0.02 & 0.02 & 0.06 & 0.36 & 104.75 & 100.49 & 3195 \\
\hline 6 & $\begin{array}{l}\text { A. frutescens subsp. parviforum, } \\
\text { A. frutescens subsp. foeniculaceum } \\
\text { (La Gomera) }\end{array}$ & $\begin{array}{l}\text { A. frutescens subsp. succulentum } \\
\text { (Tenerife) }\end{array}$ & $\begin{array}{l}\text { A. broussonetii subsp. broussonetii } \\
\text { (Tenerife) }\end{array}$ & $0.29 *$ & 0.29 & 0.06 & 4.57 & 114.54 & 62.85 & 2905 \\
\hline 7 & $\begin{array}{l}\text { A. frutescens subsp. parviforum, } \\
\text { A. frutescens subsp. foeniculaceum } \\
\text { (La Gomera) }\end{array}$ & $\begin{array}{l}\text { A. vincentii } \\
\text { (Tenerife) }\end{array}$ & $\begin{array}{l}\text { A. broussonetii subsp. broussonetii } \\
\text { (Tenerife) }\end{array}$ & 0.05 & 0.04 & 0.07 & 0.66 & 60.87 & 55.49 & 2389 \\
\hline 8 & $\begin{array}{l}\text { A. frutescens subsp. parviforum, } \\
\text { A. frutescens subsp. foeniculaceum } \\
\text { (La Gomera) }\end{array}$ & $\begin{array}{l}\text { A. gracile } \\
\text { (Tenerife) }\end{array}$ & $\begin{array}{l}\text { A. broussonetii subsp. broussonetii } \\
\text { (Tenerife) }\end{array}$ & 0.07 & 0.07 & 0.06 & 1.18 & 105.62 & 92.53 & 3554 \\
\hline 9 & $\begin{array}{l}\text { A. frutescens subsp. parviforum, } \\
\text { A. frutescens subsp. foeniculaceum } \\
\text { (La Gomera) }\end{array}$ & $\begin{array}{l}\text { A. frutescens subsp. frutescens } \\
\text { (Tenerife) }\end{array}$ & $\begin{array}{l}\text { A. broussonetii subsp. broussonetii } \\
\text { (Tenerife) }\end{array}$ & $0.20 *$ & 0.20 & 0.04 & 4.58 & 132.42 & 88.74 & 3700 \\
\hline
\end{tabular}




\begin{tabular}{|c|c|c|c|c|c|c|c|c|c|c|}
\hline 10 & $\begin{array}{l}\text { A. callichrysum, } \\
\text { A. broussonetii subsp. gomerensis } \\
\text { (La Gomera) }\end{array}$ & $\begin{array}{l}\text { A. tenerifae, } \\
\text { A. adauctum subsp. adauctum, } \\
\text { A. adauctum subsp. dugorii } \\
\text { (Tenerife) }\end{array}$ & $\begin{array}{l}\text { A. broussonetii subsp. broussonetii } \\
\text { (Tenerife) }\end{array}$ & $0.21 *$ & 0.21 & 0.04 & 4.65 & 190.82 & 125.04 & 3818 \\
\hline 11 & $\begin{array}{l}\text { A. callichrysum, } \\
\text { A. broussonetii subsp. gomerensis } \\
\text { (La Gomera) }\end{array}$ & $\begin{array}{l}\text { A. foeniculaceum, } \\
\text { A. coronopifolium } \\
\text { (Tenerife) }\end{array}$ & $\begin{array}{l}\text { A. broussonetii subsp. broussonetii } \\
\text { (Tenerife) }\end{array}$ & $0.23 *$ & 0.23 & 0.05 & 4.81 & 187.39 & 116.85 & 3619 \\
\hline 12 & $\begin{array}{l}\text { A. frutescens subsp. parviforum, } \\
\text { A. frutescens subsp. foeniculaceum } \\
\text { (La Gomera) }\end{array}$ & $\begin{array}{l}\text { A. vincentii } \\
\text { (Tenerife) }\end{array}$ & $\begin{array}{l}\text { A. frutescens subsp. succulentum } \\
\text { (Tenerife) }\end{array}$ & -0.03 & -0.04 & 0.06 & 0.55 & 89.58 & 96.05 & 2107 \\
\hline 13 & $\begin{array}{l}\text { A. frutescens subsp. parviforum, } \\
\text { A. frutescens subsp. foeniculaceum } \\
\text { (La Gomera) }\end{array}$ & $\begin{array}{l}\text { A. gracile } \\
\text { (Tenerife) }\end{array}$ & $\begin{array}{l}\text { A. frutescens subsp. succulentum } \\
\text { (Tenerife) }\end{array}$ & -0.04 & -0.04 & 0.05 & 0.79 & 133.53 & 143.57 & 2920 \\
\hline 14 & $\begin{array}{l}\text { A. frutescens subsp. parviforum, } \\
\text { A. frutescens subsp. foeniculaceum } \\
\text { (La Gomera) }\end{array}$ & $\begin{array}{l}\text { A. frutescens subsp. frutescens } \\
\text { (Tenerife) }\end{array}$ & $\begin{array}{l}\text { A. frutescens subsp. succulentum } \\
\text { (Tenerife) }\end{array}$ & -0.05 & -0.05 & 0.04 & 1.27 & 138.19 & 152.26 & 3010 \\
\hline 15 & $\begin{array}{l}\text { A. callichrysum, } \\
\text { A. broussonetii subsp. gomerensis } \\
\text { (La Gomera) }\end{array}$ & $\begin{array}{l}\text { A. tenerifae, } \\
\text { A. adauctum subsp. adauctum, } \\
\text { A. adauctum subsp. dugorii } \\
\text { (Tenerife) }\end{array}$ & $\begin{array}{l}\text { A. frutescens subsp. succulentum } \\
\text { (Tenerife) }\end{array}$ & $0.33 *$ & 0.33 & 0.05 & 6.89 & 169.65 & 85.76 & 2956 \\
\hline 16 & $\begin{array}{l}\text { A. callichrysum, } \\
\text { A. broussonetii subsp. gomerensis } \\
\text { (La Gomera) }\end{array}$ & $\begin{array}{l}\text { A. foeniculaceum, } \\
\text { A. coronopifolium } \\
\text { (Tenerife) }\end{array}$ & $\begin{array}{l}\text { A. frutescens subsp. succulentum } \\
\text { (Tenerife) }\end{array}$ & $0.40 *$ & 0.40 & 0.05 & 8.29 & 175.03 & 74.25 & 2805 \\
\hline 17 & $\begin{array}{l}\text { A. frutescens subsp. parviforum, } \\
\text { A. frutescens subsp. foeniculaceum } \\
\text { (La Gomera) }\end{array}$ & $\begin{array}{l}\text { A. gracile } \\
\text { (Tenerife) }\end{array}$ & $\begin{array}{l}\text { A. vincentii } \\
\text { (Tenerife) }\end{array}$ & 0.06 & 0.05 & 0.05 & 1.04 & 104.32 & 93.39 & 2414 \\
\hline 18 & $\begin{array}{l}\text { A. frutescens subsp. parviforum, } \\
\text { A. frutescens subsp. foeniculaceum } \\
\text { (La Gomera) }\end{array}$ & $\begin{array}{l}\text { A. frutescens subsp. frutescens } \\
\text { (Tenerife) }\end{array}$ & $\begin{array}{l}\text { A. vincentii } \\
\text { (Tenerife) }\end{array}$ & 0.08 & 0.08 & 0.04 & 1.96 & 126.28 & 106.86 & 2493 \\
\hline 19 & $\begin{array}{l}\text { A. callichrysum, } \\
\text { A. broussonetii subsp. gomerensis } \\
\text { (La Gomera) }\end{array}$ & $\begin{array}{l}\text { A. tenerifae, } \\
\text { A. adauctum subsp. adauctum, } \\
\text { A. adauctum subsp. dugorii } \\
\text { (Tenerife) }\end{array}$ & $\begin{array}{l}\text { A. vincentii } \\
\text { (Tenerife) }\end{array}$ & $0.35 *$ & 0.35 & 0.05 & 6.86 & 131.82 & 63.08 & 2406 \\
\hline
\end{tabular}




\begin{tabular}{|c|c|c|c|c|c|c|c|c|c|c|}
\hline 20 & $\begin{array}{l}\text { A. callichrysum, } \\
\text { A. broussonetii subsp. gomerensis } \\
\text { (La Gomera) }\end{array}$ & $\begin{array}{l}\text { A. foeniculaceum, } \\
\text { A. coronopifolium } \\
\text { (Tenerife) }\end{array}$ & $\begin{array}{l}\text { A. vincentii } \\
\text { (Tenerife) }\end{array}$ & 0.23 & 0.23 & 0.06 & 3.60 & 102.71 & 64.17 & 2300 \\
\hline 21 & $\begin{array}{l}\text { A. frutescens subsp. parviforum, } \\
\text { A. frutescens subsp. foeniculaceum } \\
\text { (La Gomera) }\end{array}$ & $\begin{array}{l}\text { A. frutescens subsp. frutescens } \\
\text { (Tenerife) }\end{array}$ & $\begin{array}{l}\text { A. gracile } \\
\text { (Tenerife) }\end{array}$ & -0.04 & -0.04 & 0.03 & 1.31 & 199.51 & 217.19 & 3698 \\
\hline 22 & $\begin{array}{l}\text { A. callichrysum, } \\
\text { A. broussonetii subsp. gomerensis } \\
\text { (La Gomera) }\end{array}$ & $\begin{array}{l}\text { A. tenerifae, } \\
\text { A. adauctum subsp. adauctum, } \\
\text { A. adauctum subsp. dugorii } \\
\text { (Tenerife) }\end{array}$ & $\begin{array}{l}\text { A. gracile } \\
\text { (Tenerife) }\end{array}$ & $0.33 *$ & 0.32 & 0.04 & 7.90 & 229.48 & 116.68 & 3663 \\
\hline 23 & $\begin{array}{l}\text { A. callichrysum, } \\
\text { A. broussonetii subsp. gomerensis } \\
\text { (La Gomera) }\end{array}$ & $\begin{array}{l}\text { A. foeniculaceum, } \\
\text { A. coronopifolium } \\
\text { (Tenerife) }\end{array}$ & $\begin{array}{l}\text { A. gracile } \\
\text { (Tenerife) }\end{array}$ & $0.22 *$ & 0.22 & 0.04 & 4.99 & 177.87 & 112.93 & 3462 \\
\hline 24 & $\begin{array}{l}\text { A. callichrysum, } \\
\text { A. broussonetii subsp. gomerensis } \\
\text { (La Gomera) }\end{array}$ & $\begin{array}{l}\text { A. tenerifae, } \\
\text { A. adauctum subsp. adauctum, } \\
\text { A. adauctum subsp. dugorii } \\
\text { (Tenerife) }\end{array}$ & $\begin{array}{l}\text { A. frutescens subsp. frutescens } \\
\text { (Tenerife) }\end{array}$ & $0.31 *$ & 0.31 & 0.04 & 8.70 & 229.20 & 120.12 & 3855 \\
\hline 25 & $\begin{array}{l}\text { A. callichrysum, } \\
\text { A. broussonetii subsp. gomerensis } \\
\text { (La Gomera) }\end{array}$ & $\begin{array}{l}\text { A. foeniculaceum, } \\
\text { A. coronopifolium } \\
\text { (Tenerife) }\end{array}$ & $\begin{array}{l}\text { A. frutescens subsp. frutescens } \\
\text { (Tenerife) }\end{array}$ & $0.24 *$ & 0.24 & 0.04 & 5.58 & 182.17 & 112.17 & 3646 \\
\hline 26 & $\begin{array}{l}\text { A. callichrysum, } \\
\text { A. broussonetii subsp. gomerensis } \\
\text { (La Gomera) }\end{array}$ & $\begin{array}{l}\text { A. foeniculaceum, } \\
\text { A. coronopifolium } \\
\text { (Tenerife) }\end{array}$ & $\begin{array}{l}\text { A. tenerifae, } \\
\text { A. adauctum subsp. adauctum, } \\
\text { A. adauctum subsp. dugorii } \\
\text { (Tenerife) }\end{array}$ & $0.19 *$ & 0.19 & 0.04 & 4.63 & 233.85 & 158.98 & 3754 \\
\hline 27 & $\begin{array}{l}\text { A. callichrysum, } \\
\text { A. broussonetii subsp. gomerensis } \\
\text { (La Gomera) }\end{array}$ & $\begin{array}{l}\text { A. adauctum subsp. canariense, } \\
\text { A. adauctum subsp. gracile, } \\
\text { A. adauctum subsp. jacobaefolium } \\
\text { (Gran Canaria) }\end{array}$ & $\begin{array}{l}\text { A. frutescens subsp. canariense } \\
\text { (Gran Canaria) }\end{array}$ & $0.32 *$ & 0.32 & 0.06 & 5.49 & 108.38 & 55.25 & 2425 \\
\hline 28 & $\begin{array}{l}\text { A. callichrysum, } \\
\text { A. broussonetii subsp. gomerensis } \\
\text { (La Gomera) }\end{array}$ & $\begin{array}{l}\text { A. filifolium, } \\
\text { A. escarrei, } \\
\text { A. lidii } \\
\text { (Gran Canaria) }\end{array}$ & $\begin{array}{l}\text { A. frutescens subsp. canariense } \\
\text { (Gran Canaria) }\end{array}$ & $0.28 *$ & 0.28 & 0.06 & 4.56 & 114.55 & 64.73 & 2397 \\
\hline
\end{tabular}


29 A. tenerifae,

A. adauctum subsp. adauctum

A. adauctum subsp. dugorii

(Tenerife)

30 A. callichrysum

(La Gomera)

31 A. filifolium,

A. escarrei,

A. lidii

(Gran Canaria)

32 A. callichrysum

A. broussonetii subsp. gomerensis

(La Gomera)

33 A. callichrysum

A. broussonetii subsp. gomerensis

(La Gomera)
A. adauctum subsp. canariense, A. filifolium,

A. adauctum subsp. gracile,

A. escarrei,

A. adauctum subsp. jacobaefolium A. lidii

(Gran Canaria)

(Gran Canaria)

A. broussonetii subsp. gomerensis (La Gomera)

A. broussoneti
(Tenerife)

A. adauctum subsp. canariense, A. adauctum subsp. adauctum,

A. adauctum subsp. dugori

A. adauctum subsp gracile

A. adauctum
(Tenerife)

A. adauctum subsp. jacobaefolium (Tenerife)

(Gran Canaria)

A. adauctum subsp. erythrocarpon, A. adauctum subsp. adauctum,

$0.14 \quad 0.14$

0.04

3.20

$192.39 \quad 145.92 \quad 3720$

adactum subsp. palmensis

A adauctum subsp. dugorii

(Tenerife)

(El Hierro)

A. adauctum subsp. canariense,

$0.08 \quad 0.08$

0.04

$\begin{array}{llll}1.81 & 168.37 & 144.59 & 3733\end{array}$

A. adauctum subsp. palmensis A adauctum subsp gracile,

(El Hierro)

A. adauctum subsp. jacobaefolium

(Gran Canaria) 


\section{Figures}

Fig. 1 Madeira, Selvagem Pequena and Canary Islands in the North Atlantic Ocean and the taxa in Argyranthemum occurring on each island that were sampled for this study.

Fig. 2 (a) Diagrams of the events identified in the biogeographical stochastic mapping analyses adapted from Matzke (2020). Anagenetic events include range expansion and contraction. Cladogenetic events include intra-range speciation (narrow and subset) and vicariance. In the context of the oceanic islands we interpret vicariance inter-island allopatric speciation for geography and habitat shifts for habitat data respectively. (b-e) Four taxon pectinate trees for D-statistics showing (b) ABBA and (c) BABA allele distributions where red arrows indicate hybridisation events between $\mathrm{P} 3$ and $\mathrm{P} 2$ or $\mathrm{P} 1$ and $\mathrm{D}$-statistics testing for (d) hybridisation between lineages from the same island and (e) between multiple island endemic lineages.

Fig. 3 Maximum likelihood tree of Argyranthemum generated using RAxML-NG for the dataset based on a clustering threshold of $90 \%$ and minimum sample number of 30 . Branch lengths are shown except for outgroup taxa from Glebionis which were truncated to equal the longest branch length in Argyranthemum. Bootstrap values $\geq 70$ are shown above the branches and posterior probabilities $\geq 0.95$ from MrBayes are shown below the branches. Tips are coloured by island and clades A-G are discussed in the Results section (see phylogenetic reconstruction). A scale bar proportional to branch length is also shown.

Fig. 4 Ancestral range estimation in Argyranthemum for geography (left) and habitat (right) performed in BioGeoBEARS using DIVALIKE and BAYAREALIKE models respectively. The annotation on each node shows the most likely ancestral range for each model. Geographical states are abbreviated as: M (Madeira), S (Selvagem Pequena), L (Lanzarote), F (Fuerteventura), C (Gran Canaria), T (Tenerife), P (La Palma), G (La Gomera) and H (El Hierro). Habitat states are abbreviated as: $\mathrm{E}$ (Euphorbia scrubland), T (thermo-sclerophyllous woodland), L (laurel forest), $\mathrm{P}$ (pine forest) and $S$ (subalpine zone). Clades A-G are the same as those in figure 3 and are discussed in the Results section (see phylogenetic reconstruction).

Fig. 5 Number of dispersal events estimated in Argyranthemum for (a) geography and (b) habitat. Counts of dispersal events were averaged across the 50 biogeographic stochastic models. The frequency of event is denoted by colour, with warmer colours indicating a higher frequency. The direction of dispersal is from the row state to the column state. The sum and percentages of events involving each area, either as a source (rows) or sink (columns) are given on the margins.

Geographical states are abbreviated as: M (Madeira), S (Selvagem Pequena), L (Lanzarote), F (Fuerteventura), C (Gran Canaria), T (Tenerife), P (La Palma), G (La Gomera) and H (El Hierro). Habitat states are abbreviated as: E (Euphorbia scrubland), $\mathrm{T}$ (thermo-sclerophyllous woodland), L (laurel forest), $\mathrm{P}$ (pine forest) and $\mathrm{S}$ (subalpine zone). 


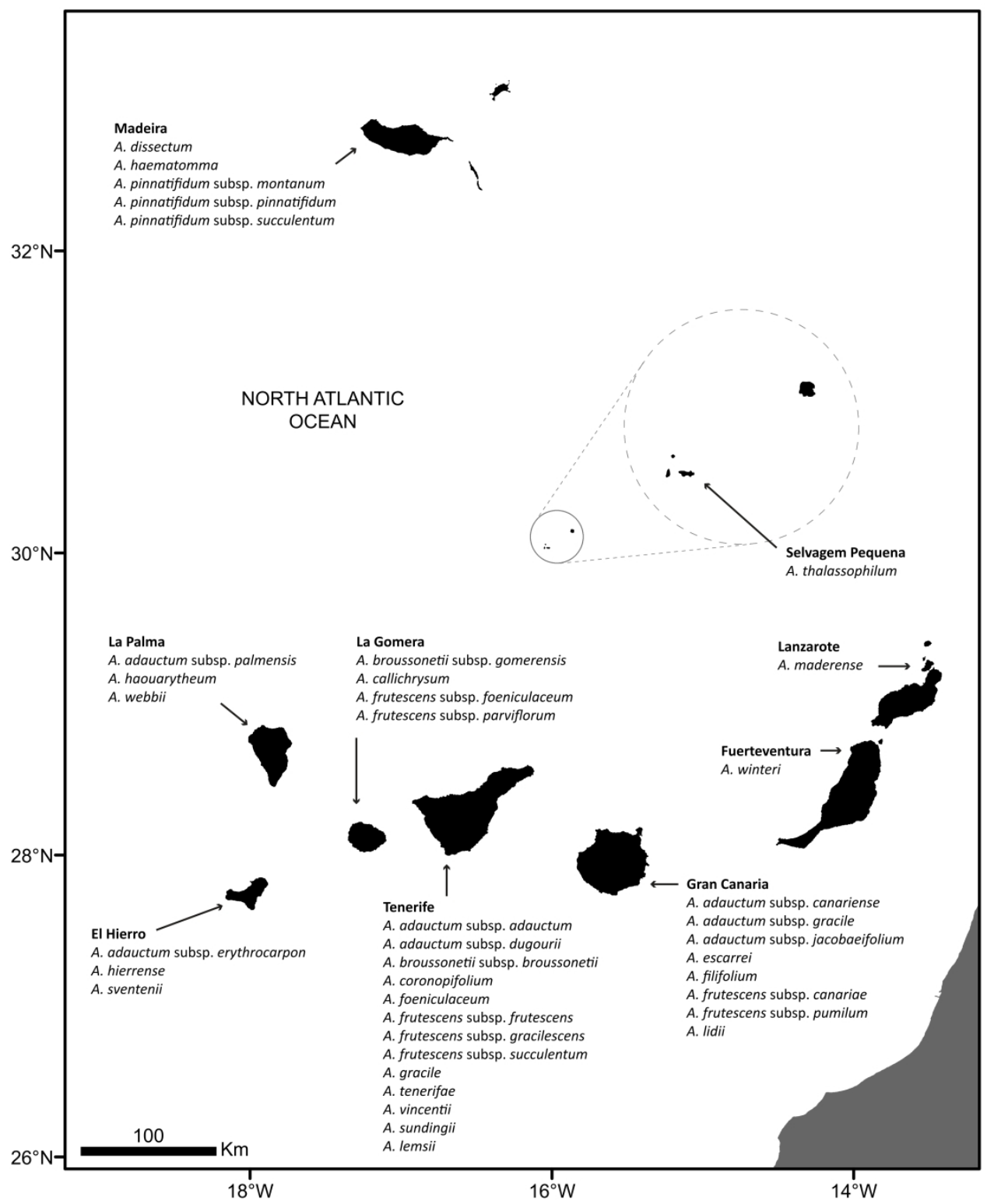

Madeira, Selvagem Pequena and Canary Islands in the North Atlantic Ocean and the taxa in Argyranthemum occurring on each island that were sampled for this study. 
(a)

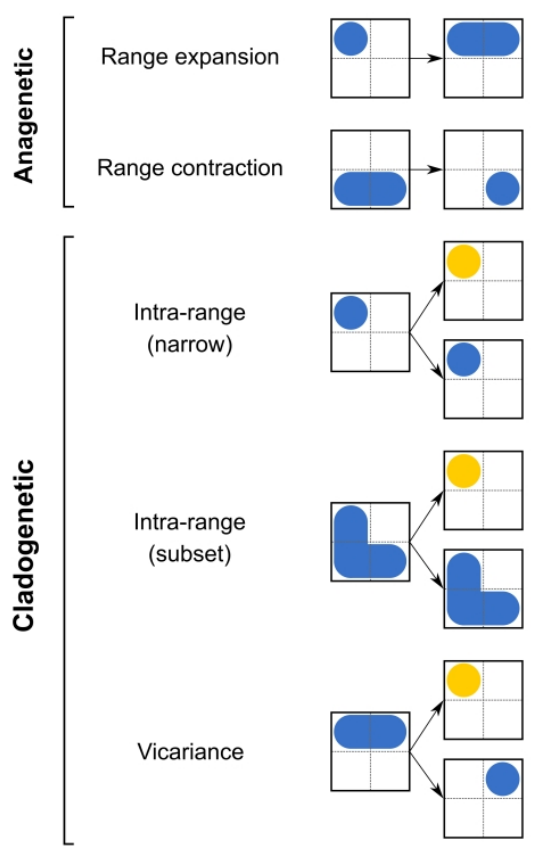

(b)

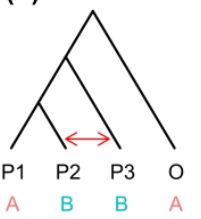

(d)

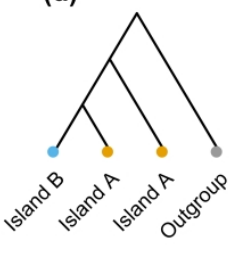

(c)

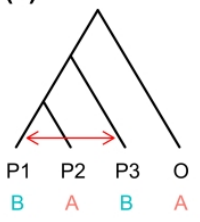

(e)

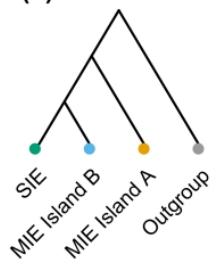

(a) Diagrams of the events identified in the biogeographical stochastic mapping analyses adapted from Matzke (2020). Anagenetic events include range expansion and contraction. Cladogenetic events include intra-range speciation (narrow and subset) and vicariance. In the context of the oceanic islands we interpret vicariance inter-island allopatric speciation for geography and habitat shifts for habitat data respectively. (be) Four taxon pectinate trees for D-statistics showing (b) ABBA and (c) BABA allele distributions where red arrows indicate hybridisation events between P3 and P2 or P1 and D-statistics testing for (d) hybridisation between lineages from the same island and (e) between multiple island endemic lineages. 


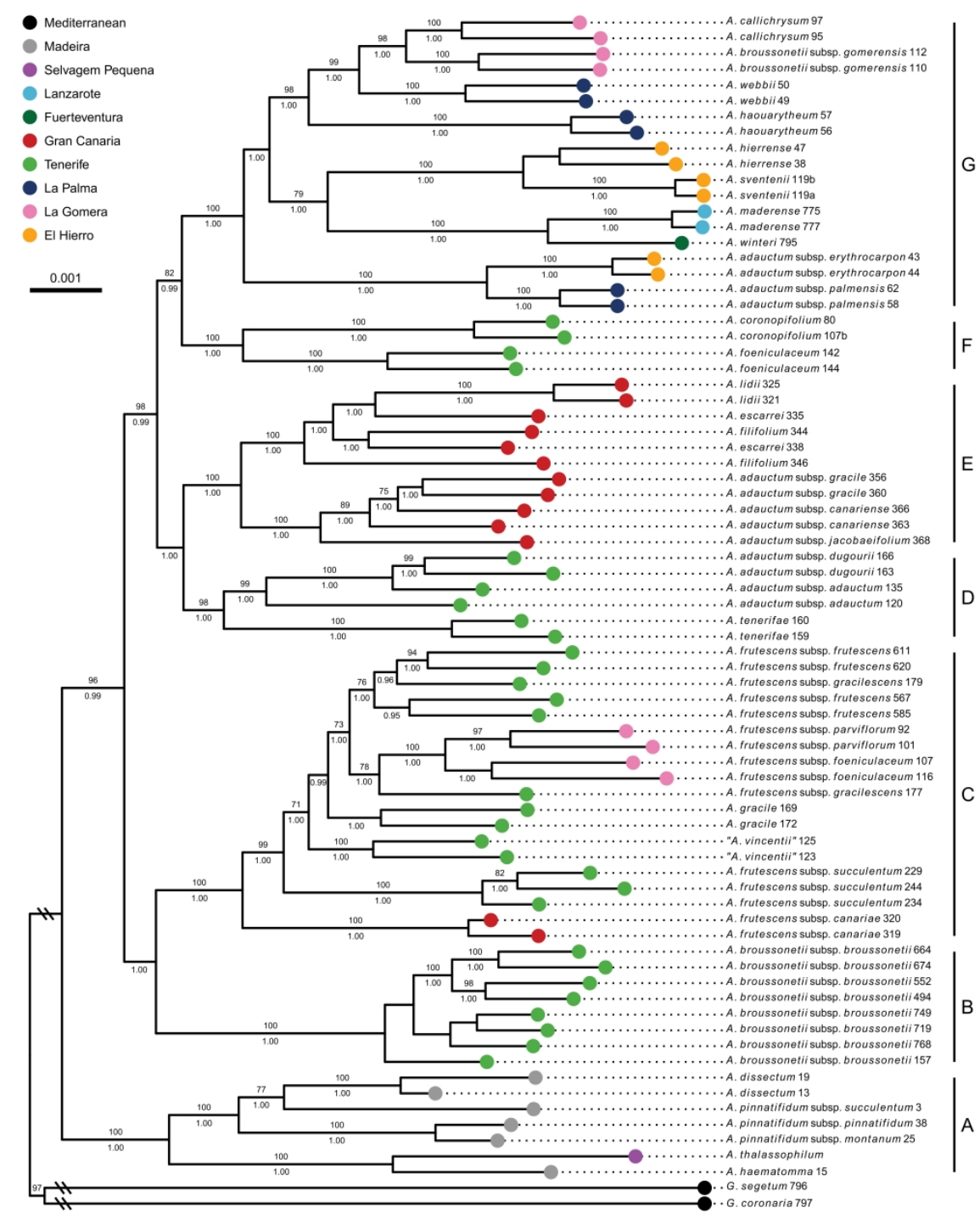

Maximum likelihood tree of Argyranthemum generated using RAxML-NG for the dataset based on a clustering threshold of $90 \%$ and minimum sample number of 30 . Branch lengths are shown except for outgroup taxa from Glebionis which were truncated to equal the longest branch length in Argyranthemum. Bootstrap values $\geq 70$ are shown above the branches and posterior probabilities $\geq 0.95$ from MrBayes are shown below the branches. Tips are coloured by island and clades A-G are discussed in the Results section (see phylogenetic reconstruction). A scale bar proportional to branch length is also shown. 

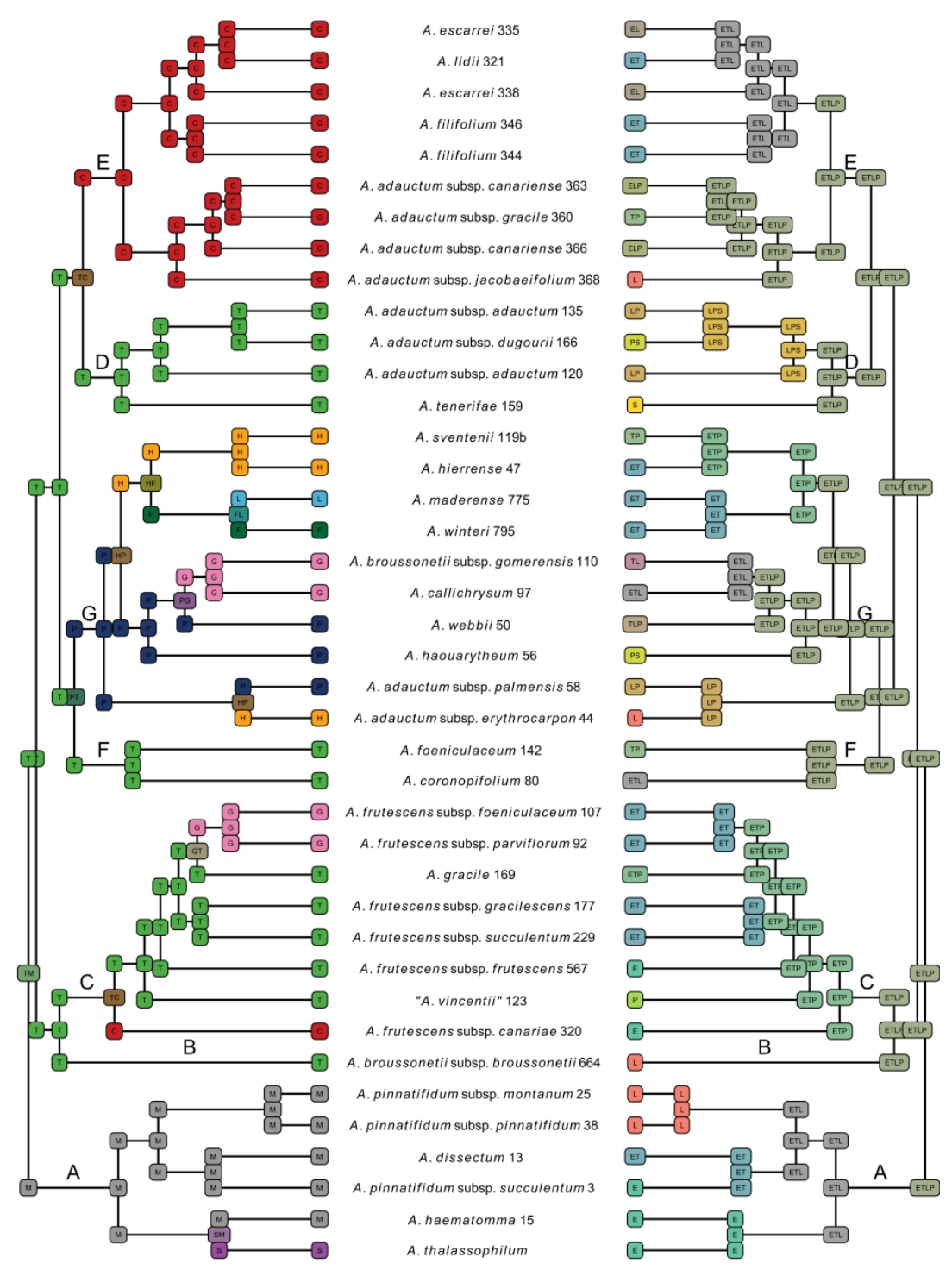

Ancestral range estimation in Argyranthemum for geography (left) and habitat (right) performed in BioGeoBEARS using DIVALIKE and BAYAREALIKE models respectively. The annotation on each node shows the most likely ancestral range for each model. Geographical states are abbreviated as: M (Madeira), S (Selvagem Pequena), L (Lanzarote), F (Fuerteventura), C (Gran Canaria), T (Tenerife), P (La Palma), G (La Gomera) and H (El Hierro). Habitat states are abbreviated as: E (Euphorbia scrubland), T (thermosclerophyllous woodland), L (laurel forest), P (pine forest) and S (subalpine zone). Clades A-G are the same as those in figure 3 and are discussed in the Results section (see phylogenetic reconstruction). 
(a)

\begin{tabular}{|c|c|c|c|c|c|c|c|c|c|c|}
\hline & H & $\mathbf{P}$ & G & $\mathbf{T}$ & C & $\mathbf{F}$ & L & $\mathbf{S}$ & $\mathbf{M}$ & \\
\hline & - & $\begin{array}{c}0.70 \\
(0.95)\end{array}$ & $\begin{array}{c}0.02 \\
(0.14)\end{array}$ & $\begin{array}{c}0.00 \\
(0.00)\end{array}$ & $\begin{array}{c}0.00 \\
(0.00)\end{array}$ & $\begin{array}{c}0.28 \\
(0.45)\end{array}$ & $\begin{array}{c}0.24 \\
(0.43)\end{array}$ & $\begin{array}{c}0.00 \\
(0.00)\end{array}$ & $\begin{array}{c}0.00 \\
(0.00)\end{array}$ & $\begin{array}{c}1.24 \\
12.33 \%\end{array}$ \\
\hline & $\begin{array}{c}0.90 \\
(0.79)\end{array}$ & - & $\begin{array}{c}0.96 \\
(0.20)\end{array}$ & $\begin{array}{c}0.00 \\
(0.00)\end{array}$ & $\begin{array}{c}0.00 \\
(0.00)\end{array}$ & $\begin{array}{c}0.28 \\
(0.45)\end{array}$ & $\begin{array}{c}0.24 \\
(0.43)\end{array}$ & $\begin{array}{c}0.00 \\
(0.00)\end{array}$ & $\begin{array}{c}0.00 \\
(0.00)\end{array}$ & $\begin{array}{c}2.38 \\
23.66 \%\end{array}$ \\
\hline & $\begin{array}{c}0.00 \\
(0.00)\end{array}$ & $\begin{array}{c}0.06 \\
(0.31)\end{array}$ & 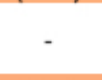 & $\begin{array}{c}0.00 \\
(0.00)\end{array}$ & $\begin{array}{c}0.00 \\
(0.00)\end{array}$ & $\begin{array}{c}0.00 \\
(0.00)\end{array}$ & $\begin{array}{c}0.00 \\
(0.00)\end{array}$ & $\begin{array}{c}0.00 \\
(0.00)\end{array}$ & $\begin{array}{c}0.00 \\
(0.00)\end{array}$ & $\begin{array}{c}0.06 \\
0.60 \%\end{array}$ \\
\hline & $\begin{array}{c}0.36 \\
(0.48)\end{array}$ & $\begin{array}{c}0.64 \\
(0.48)\end{array}$ & $\begin{array}{c}1.00 \\
(0.00)\end{array}$ & - & $\begin{array}{c}2.00 \\
(0.00)\end{array}$ & $\begin{array}{c}0.00 \\
(0.00)\end{array}$ & $\begin{array}{c}0.00 \\
(0.00)\end{array}$ & $\begin{array}{c}0.00 \\
(0.00)\end{array}$ & $\begin{array}{c}0.00 \\
(0.00)\end{array}$ & $\begin{array}{c}4.00 \\
39.76 \%\end{array}$ \\
\hline & $\begin{array}{c}0.00 \\
(0.00)\end{array}$ & $\begin{array}{c}0.00 \\
(0.00)\end{array}$ & $\begin{array}{c}0.00 \\
(0.00)\end{array}$ & $\begin{array}{c}0.00 \\
(0.00)\end{array}$ & . & $\begin{array}{c}0.00 \\
(0.00)\end{array}$ & $\begin{array}{c}0.00 \\
(0.00)\end{array}$ & $\begin{array}{c}0.00 \\
(0.00)\end{array}$ & $\begin{array}{c}0.00 \\
(0.00)\end{array}$ & $\begin{array}{c}0.00 \\
0.00 \% \\
\end{array}$ \\
\hline & $\begin{array}{c}0.20 \\
(0.40)\end{array}$ & $\begin{array}{c}0.00 \\
(0.00)\end{array}$ & $\begin{array}{c}0.00 \\
(0.00)\end{array}$ & $\begin{array}{c}0.00 \\
(0.00)\end{array}$ & $\begin{array}{c}0.00 \\
(0.00)\end{array}$ & - & $\begin{array}{c}0.52 \\
(0.50)\end{array}$ & $\begin{array}{c}0.00 \\
(0.00)\end{array}$ & $\begin{array}{c}0.00 \\
(0.00)\end{array}$ & $\begin{array}{c}0.72 \\
7.16 \%\end{array}$ \\
\hline & $\begin{array}{c}0.18 \\
(0.39)\end{array}$ & $\begin{array}{c}0.00 \\
(0.00)\end{array}$ & $\begin{array}{c}0.02 \\
(0.14)\end{array}$ & $\begin{array}{c}0.00 \\
(0.00)\end{array}$ & $\begin{array}{c}0.00 \\
(0.00)\end{array}$ & $\begin{array}{c}0.44 \\
(0.50)\end{array}$ & 8 & & $\begin{array}{c}0.00 \\
(0.00)\end{array}$ & $\begin{array}{c}0.64 \\
6.36 \%\end{array}$ \\
\hline & $\begin{array}{c}0.00 \\
(0.00)\end{array}$ & $\begin{array}{c}0.00 \\
(0.00)\end{array}$ & $\begin{array}{c}0.00 \\
(0.00)\end{array}$ & $\begin{array}{c}0.00 \\
(0.00)\end{array}$ & $\begin{array}{c}0.00 \\
(0.00)\end{array}$ & $\begin{array}{c}0.00 \\
(0.00)\end{array}$ & $\begin{array}{c}0.00 \\
(0.00)\end{array}$ & - & $\begin{array}{c}0.18 \\
(0.39)\end{array}$ & $\begin{array}{c}0.18 \\
1.79 \%\end{array}$ \\
\hline & $\begin{array}{c}0.00 \\
(0.00)\end{array}$ & $\begin{array}{c}0.00 \\
(0.00)\end{array}$ & $\begin{array}{c}0.00 \\
(0.00)\end{array}$ & $\begin{array}{c}0.00 \\
(0.00)\end{array}$ & $\begin{array}{c}0.00 \\
(0.00)\end{array}$ & $\begin{array}{c}0.00 \\
(0.00)\end{array}$ & $\begin{array}{c}0.00 \\
(0.00)\end{array}$ & $\begin{array}{c}0.84 \\
(0.37)\end{array}$ & - & $\begin{array}{c}0.84 \\
8.35 \%\end{array}$ \\
\hline & $\begin{array}{c}1.64 \\
16.30 \%\end{array}$ & $\begin{array}{c}1.40 \\
13.92 \%\end{array}$ & $\begin{array}{c}2.00 \\
19.88 \%\end{array}$ & $\begin{array}{c}0.00 \\
0.00 \%\end{array}$ & $\begin{array}{c}2.00 \\
19.88 \%\end{array}$ & $\begin{array}{c}1.00 \\
9.94 \%\end{array}$ & $\begin{array}{c}1.00 \\
9.94 \%\end{array}$ & $\begin{array}{c}0.84 \\
8.35 \%\end{array}$ & $\begin{array}{c}0.18 \\
1.79 \%\end{array}$ & $\begin{array}{c}10.06 \\
100.00 \%\end{array}$ \\
\hline
\end{tabular}

(b)

\begin{tabular}{cccccccc} 
& $\mathbf{E}$ & $\mathbf{T}$ & $\mathbf{L}$ & $\mathbf{P}$ & $\mathbf{S}$ & \\
$\mathbf{E}$ & & 0.64 & 0.34 & 0.6 & 0.76 & 2.34 \\
& - & $(0.72)$ & $(0.59)$ & $(0.83)$ & $(0.72)$ & $30.15 \%$ \\
$\mathbf{T}$ & 0.24 & & 0.24 & 0.78 & 0.70 & 1.96 \\
& $(0.56)$ & - & $(0.52)$ & $(0.86)$ & $(0.76)$ & $25.26 \%$ \\
$\mathbf{L}$ & 0.24 & 0.3 & & 0.30 & 0.76 & 1.6 \\
& $(0.52)$ & $(0.51)$ & - & $(0.51)$ & $(0.77)$ & $20.62 \%$ \\
\hline & 0.14 & 0.22 & 0.32 & & 1.04 & 1.72 \\
& $(0.35)$ & $(0.58)$ & $(0.55)$ & - & $(0.88)$ & $22.16 \%$ \\
\hline & 0.00 & 0.04 & 0.06 & 0.04 & & 0.14 \\
& $(0.00)$ & $(0.20)$ & $(0.24)$ & $(0.20)$ & - & $1.80 \%$ \\
\hline & 0.62 & 1.2 & 0.96 & 1.72 & 3.26 & 7.76 \\
& $7.99 \%$ & $15.46 \%$ & $12.37 \%$ & $22.16 \%$ & $42.01 \%$ & $100.00 \%$
\end{tabular}

Number of dispersal events estimated in Argyranthemum for (a) geography and (b) habitat. Counts of dispersal events were averaged across the 50 biogeographic stochastic models. The frequency of event is denoted by colour, with warmer colours indicating a higher frequency. The direction of dispersal is from the row state to the column state. The sum and percentages of events involving each area, either as a source (rows) or sink (columns) are given on the margins. Geographical states are abbreviated as: M (Madeira), S (Selvagem Pequena), L (Lanzarote), F (Fuerteventura), C (Gran Canaria), T (Tenerife), P (La Palma), G (La

Gomera) and H (El Hierro). Habitat states are abbreviated as: E (Euphorbia scrubland), T (thermosclerophyllous woodland), L (laurel forest), P (pine forest) and S (subalpine zone). 